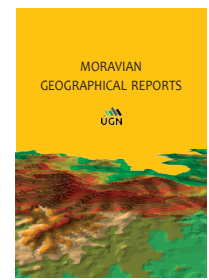

\title{
The importance of historical maps for man-made pond research: From the past extent of ponds to issues of the present landscape. A case study from the Czech Republic
}

\author{
Jindřich FRAJER ${ }^{\text {a }}$, Jana KREMLOVÁ a , David FIEDOR ${ }^{\text {a }}$, \\ Renata PAVELKOVÁ a , Miroslav TRNKA ${ }^{\text {b,c }}$
}

\begin{abstract}
Historical maps are a valuable resource in landscape research. The information gathered from them facilitates the cognisance of landscapes and may assist current landscape planning. This study focuses on the historical occurrence and spatial extent of man-made ponds in the Czech Republic. Based on the $1^{\text {st }}$ Military Survey maps (1764-1783) of the Habsburg Monarchy, we use Historical GIS to identify 7,676 man-made ponds in the historical landscape. Compared to the $2^{\text {nd }}$ Military Survey maps (1836-1852), 56\% of these man-made ponds had been drained. Such disappearances mostly affected large ponds in fertile agricultural areas, but also affected small reservoirs in less fertile areas at higher altitudes. As the current maps and spatial datasets (Water reservoirs, Landscape water regime, Farming areas) show, a number of these agricultural regions have been affected by climate changes and face water shortages. The historical map information of former ponds has the potential to contribute to their restoration in areas where water retention in the landscape needs to be increased.
\end{abstract}

Keywords: ponds; water regime; historical GIS; historical maps; Czech Republic

Article history: Received 25 February 2021, Accepted 29 July 2021, Published 30 September 2021

\section{Introduction}

Historical maps are an important source of information on the historical landscape (Podobnikar, 2010; Pindozzi et al., 2016). Their popularity is growing, and they are used more commonly in the academic sphere, which is reflected in the number of published studies that utilise them (Chiang et al., 2020, p. 5). Historical maps are more beneficial in comparison with other sources, mainly in providing rapid spatial information on a given phenomenon without the need to study the auxiliary science of history (Trpáková, 2009). They are more widely available online to both experts and the public with increased digital access (Southdall and Přidal, 2012). Historical map processing in geographical information systems (GIS) has proven beneficial in many disciplines. The information acquired in this manner can be combined with other sources of spatial data. Processing historical materials in GIS is often referred to as Historical GIS (HGIS) (Knowles, 2002). It allows researchers to gain new insights about the past as well as to expand its application throughout various fields (Gregory and Geddes, 2014). HGIS traces the long-term spatial development of certain phenomena in the landscape, thus providing valuable information to other sciences dealing with current landscapes. The methods of HGIS are applied in geographic research (among others) in the study of land use development (Demek et al., 2012; Pindozzi et al., 2016), landscape diversity (Yeh and Huang, 2009), changes in natural or anthropogenic landforms (Faccini et al., 2020), and specific landscape features (Kaim et al., 2020; Brykała and Podgórski, 2020). The outcomes of such studies facilitate the understanding of the present landscape development and its functions (Skaloš, Richter and Keken, 2017; Bateman et al., 2020), allow the discovery of locations suitable for conservation (Canessa et al., 2017), or

\footnotetext{
a Department of Geography, Faculty of Science, Palacký University Olomouc (*corresponding author: J. Frajer, e-mail: jindrich.frajer@upol.cz)

${ }^{\mathrm{b}}$ Institute of Agriculture Systems and Bioclimatology, Mendel University of Agriculture and Forestry, Brno, Czech Republic

${ }^{\mathrm{c}}$ Global Change Research Centre, Czech Academy of Sciences, Brno, Czech Republic
} 
serve as a basis for modelling future landscape development (Tortora et al., 2015) and a source of inspiration for solving environmental issues in the current landscape (Antrop, 2004; Haase et al., 2007; Marignani et al., 2008).

The above-mentioned research can be documented with the example of ponds in the landscape. Ponds (natural and anthropogenic) are an integral part of the rural landscape. As such, their existence as an everyday feature of the landscape has 'prevented' expert discovery of their original role and history (Upex, 2004), and they have escaped the mainstream attention of scientists for a considerable amount of time (Jeffries, 2016; Ruggiero et al., 2008). This view has changed, together with the result of dynamic changes of European landscapes during the last two centuries (Antrop, 2004; Jeffries, 2012). A number of ponds were turned into agricultural land in the $19^{\text {th }}$ and $20^{\text {th }}$ centuries due to the intensification of agriculture (Boothby and Hull, 1997; Curado et al., 2011; Havlíček et al., 2014), cleared for advancing urbanisation (Burgin et al., 2016), and other anthropogenic activities such as mining and transport infrastructure construction (Kopp et al., 2015). Many other ponds face growing anthropogenic pressure including agricultural drainage, pollution and landfilling (Juszczak and Kedziora, 2003), as well as the impacts of climate extremes (Jeffries, 2016).

Landscapes lack other important hydrological and ecological features with the loss of ponds (Céréghino et al., 2008; Chen et al., 2019; Juszczak et al., 2007). In England, with respect to the important conservation values of ponds, historical maps began to be used to follow the longterm development of the number and density of ponds in the landscape in the mid-1980s (Jeffries, 2012; Langton, 1985). Simultaneously, the causes of their disappearance were uncovered (Boothby and Hull, 1997). Studies from the end of the last century emphasised the exceptional role of ponds as wildlife habitats; thus ponds became an important scientific as well as political topic with respect to landscape planning and landscape management (Jeffries, 2016). Historical maps allow us to uncover the extent of the loss of ponds in the landscape. Thus, official historical state surveys (Chabudziński et al., 2017; Jankowski, 2006; Jeffries, 2016), special historical atlases (Fairchild et al., 2013), as well as personal hand-drawn maps (Johnstone, 2015) and plans (Mactaggart et al., 2007), have been used and combined in the GIS environment with current maps and aerial photographs (Fairchild et al., 2013) or with Lidar data (Walter and Merritts, 2008).

Ponds have become a topic for discussion in Central Europe with respect to adaptation measures to climate change and their impact on the landscape. This concerns mostly the impact of higher frequency and duration of the period of drought in the landscape (Trnka et al., 2016). This trend has had an impact on most of Europe, which has been repeatedly affected by drought during the last decades (Barros et al., 2014), along with the recent European summer droughts starting from 2015, which are without precedence over the last two millennia (Büntgen et al., 2021). Thus, the availability of water in the landscape, whether for plants and animals or human society and its activities and needs - agriculture, aquaculture, industrial production, recreation, supplying local aquifers, water accumulation in case of fire - becomes a major problem, especially during the summer months. Ponds might play a significant role in this issue. They provide many hydrological functions such as intercepting surface run-off, reducing and postponing flood peaks, recharging and discharging groundwater, intercepting sediment in surface run-off, increasing humidity in their neighbourhoods and storing water for different human needs (Chen et al., 2019). Overall, they increase water retention in the landscape (Juszczak et al., 2007).

Building man-made ponds can also be seen as a significant anthropogenic impact on the landscape (Hoffmann, 2002), which dramatically affects natural hydrological and geomorphological processes (Walter and Merrits, 2008). Their contribution to groundwater recharging is sometimes disputed (Kale, 2017), as well as their ecological functions when they can disturb the natural migration trajectories of certain fish species (DeFries et al., 2019), change the quality of water in the watercourses (Igantius and Rasmussen, 2016), store the environmental pollutants from anthropogenic activity (Bábek et al., 2021), or create eutrophic or hypertrophic conditions due to the increased nutrient loading from agriculture and settlement (Potužák, 2016). The lack of maintenance or unsuitable management of man-made ponds may lead to the loss of some hydrological functions (Výleta, 2020), which may also cause the threat of dam burst or overflowing of man-made ponds during flood events (Lhotský, 2010).

The tradition of man-made ponds in Central European countries goes back to the Middle Ages, but most of these ponds ceased to exist at the beginning of the $19^{\text {th }}$ century (Jankowski, 2006; Pavelková et al., 2016). For the abovestated hydrological and ecological functions of man-made ponds, a gradual revitalisation and renewal of ponds with the support of the state or European subsidy programs is presently underway (Chabudziński et al., 2017; Rozkošný et al., 2020). Historical maps can play an important role in preparing the ground for pond restoration (David and Davidová, 2015).

The aims of this paper, using the example of the Czech Republic and the methods of HGIS, historical maps, and current geodata are:

i. to identify the historical man-made ponds, discover their spatial distribution in the historical landscape, and to determine the extent of their disappearance at the beginning of the $19^{\text {th }}$ century; and

ii. to determine the potential applicability of historical pond data in connection with the issues of water shortages in the current landscape.

\section{Theoretical background}

\subsection{Ponds - terminology}

The definitions of ponds vary according to the viewpoints used to evaluate them and the purposes of the study. Ponds are most commonly defined based on their size that is what distinguishes them from lakes (Moss, 2017). Chabudziński et al. (2017, p. 2) saw ponds as small manmade or natural shallow water bodies in the landscape that hold water permanently or temporarily. This corresponds to the definition presented by De Meester et al. (2005), who stated that it is complicated to distinguish between a pond and a lake, which can, similar to a pond, be of a natural or anthropogenic origin (Jánský and Šobr, 1995). While some authors perceived ponds only as "small" water bodies expanding up to 2 hectares maximum (Biggs et al., 2005; De Bie, 2008; Wood et al., 2003), others recommended extending the limit to 5 hectares (De Meester et al., 2005) or up to 100 hectares, mainly in regions without natural lakes (Renwick 
et al., 2005). Moss (2017) noted that the size limit between lakes and ponds is artificial and that ponds can be historically seen as small lakes and small lakes as large ponds. The term pond however is more commonly used in connection with human activities (fishpond, farm pond, hammer pond, etc.) (Löfller, 2001). This also holds for the Czech Republic, where the historically largest man-made ponds reached sizes from several tens of square metres up to several hundreds of hectares (Pokorný and Hauser, 2002).

The distinction between man-made ponds (sometimes called artificial ponds, e.g. Oertli, 2002; or constructed ponds, e.g. Fairchild et al., 2013) and natural ponds are often blurred as well. A number of these water bodies are up to several centuries old (Hurst et al., 2016), and their integration in the landscape makes the distinction between natural and anthropogenic origin nearly impossible (Muir, 2004). This occurs mainly because the newly created pond is soon colonised by neighbouring macrophytes (Francová et al., 2019). Some types of man-made ponds are well recognisable because of specific earthworks (e.g. dams, dykes, or feeding channels), but others were created from natural ponds located in shallow depressions, which were only deepened and expanded by digging (Rugiero et al., 2008), or they are flooded relics of past mining activities (Prince, 1962).

In this study, a distinction between man-made and natural ponds is used following Fairchild et al. (2013), who applied historical maps and aerial photograps and reduced the category of natural ponds to oxbow ponds and temporary ponds in a study about the changes in the distribution of constructed ponds in the Brandywine watershed. This category can be detected in historical maps within floodplains with elongated and typically sinuous shapes, as well as by orientations paralleling larger streams. All other ponds which are typical for their regular shape, bank conditions, dams, or outfall structures, as well as their specific land use, are then constructed (man-made) ponds. Fairchild et al. (2013) followed the conditions of their study area with a few natural lakes. The situation in the Czech Republic is similar: there are very few natural ponds and lakes and the majority of ponds are of anthropogenic origin (Björk, Pokorný and Hauser, 2010; Pavelková et al., 2016). Thus, our research considers all water bodies in historical maps to be man-made ponds (except oxbow ponds), regardless of their size.

\subsection{History of man-made ponds in the Czech Republic}

The history of the construction of artificial ponds in the Czech Republic goes back to the $10^{\text {th }}$ century, with evidence of their existence in the form of archaeological findings. The first written accounts date to documentation of the $12^{\text {th }}$ century. The records about fishponds were part of the list of properties gifted by the monarch to newly established monasteries. These records also demonstrate an interesting fact - the history of creating man-made ponds in the Czech Republic is closely linked to the term fishpond. It refers to small water reservoirs primarily serving as fish farms but was also used for all other types of ponds, whether it was sources of water for mills, watering places for cattle, or decorative ponds in the gardens of noble houses. For example, millpond in Czech (mlýnský rybník) is directly translated as mill fishpond. The preference for the term fishpond is connected with the massive construction of ponds in the $15^{\text {th }}$ and $16^{\text {th }}$ centuries due to the beneficial activity of fish farming (especially carp). Powerful noble families, royal cities, and monasteries built extensive systems of ponds that were supplied by watercourses as well as by artificial channels (Lochamn, 1970).

Originally, smaller ponds were built on small watercourses as they were less demanding technologically. As builders gained experience, however, large ponds were built in flat areas and on larger watercourses. The largest ones, including Rožmberk (South Bohemia), Velká Čeperka, and Blato (Eastern Bohemia) covered an area of up to 1,000 hectares. And it is the largest ponds and pond systems that have attracted the greatest attention of research so far in the fields of history (Teplý, 1925), geography, (Skaloš et al., 2011), and hydrobiology (Francová et al., 2019). It is estimated that in the period of the greatest boom of man-made pond building $\left(16^{\text {th }}\right.$ century), there were approximately 75,000 fishponds on the territory of the current Czech Republic (Broža et al., 2005) covering a total of 180,000 ha (Teplý, 1925). The actual number of constructed ponds is unclear, however, given the lack and fragmentation of historical resources, as well as the fact that many small fishponds were not in the interest area of the period officials and chroniclers.

As Figure 1 shows, the number of ponds currently in the Czech Republic has been declining since the Middle Ages, especially during the $18^{\text {th }}$ and $19^{\text {th }}$ centuries, when the

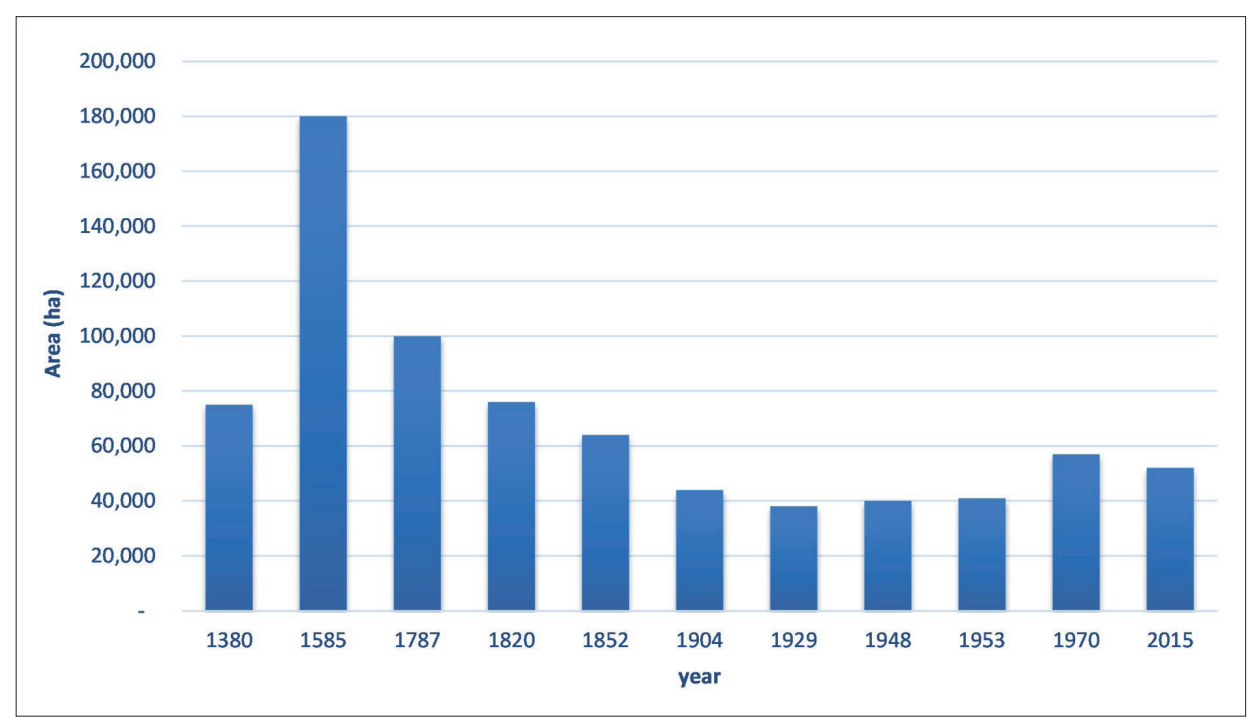

Fig. 1: Development of fishpond areas in the Czech Republic

Sources: Adapted from Teplý (1925), Růžička (1954), Jůva (1980), Pavelková et al. (2014), and Lusk (2015) 
majority of fishponds were drained. Such changes were connected to several factors, including the Enlightenment reforms (abolition of monasteries, slavery, land reforms), the poor technical condition of the fishponds, natural processes (filling with sediments or destroyed by flood), a decline in the economic yield of fish farming, as well as accelerated urbanisation - but mainly due to intensified agriculture. Regarding pond draining, two main "waves" can be identified. The first one occurred at the turn of the $18^{\text {th }}$ and $19^{\text {th }}$ centuries and the second one in the second half of the $19^{\text {th }}$ century. The "second wave" of pond destruction in the Czech Republic was surveyed in detail in the study of Pavelková et al. (2016). They identified nearly 34,000 man-made ponds of an area of 64,000 ha based on historical maps from the mid- $19^{\text {th }}$ century $\left(2^{\text {nd }}\right.$ Military survey of the Habsburg Empire). Focusing on ponds larger than 0.5 ha, more than $31 \%$ of them (over 15,000 ha) disappeared from the landscape. The "first wave" of pond destruction, which appears to be more significant based on regional studies (David and Černochová, 2020; Frajer, 2019; Skaloš et al., 2011; Šimůnek et al., 2014), however, has not yet been studied on a larger scale.

Interest in the restoration of ponds was already registered at the end of the $19^{\text {th }}$ century in connection with rediscovering carp pond management practices (Francová et al., 2019). Since the mid- $20^{\text {th }}$ century, some ponds have also been restored for agricultural purposes (irrigation). State and European subsidies to support the restoration of ponds for ecological and hydrological purposes began to be granted in the 1990s. Some 342 projects for the construction of new ponds and restoration of former ones were subsidised between 20082014 (Rozkošný et al., 2020). At present, ponds are among the topics of public and political dispute in connection with climatic change and its impact on the landscape (Ministry of Agriculture of the Czech Republic, 2019), especially the potential for their restoration.

\subsection{Study area}

The area of interest was determined with respect to the use of historical maps based on the borders of historical regions which were identifiable in the historical maps. Four historical administrative regions were included: Č́slav, Chrudim, Hradec and Bydžov (see Fig. 2a). The study area covers some $12,478 \mathrm{~km}^{2}$ and is diverse in terms of its relief, climate and soil conditions. These aspects may have influenced the disappearance of ponds. The central part of the study area contains fertile flatlands along the river Elbe and its tributaries, where historically large pond areas (Poděbrady and Pardubice regions) were located. This part of the study area is mostly affected by drought and negative water regimes (e.g. higher evapotranspiration rate than precipitation: Fig. 2b). There are mountainous areas in the north and north-east and the south and south-east are characterised by highlands. Regarding the official distribution of areas suitable for farming in the Czech Republic, three farming areas are located: a fertile beet-growing area (mostly with chernozems and fluvisols up to $300 \mathrm{~m}$ a. s. l., annual mean temperature between 8 and $9{ }^{\circ} \mathrm{C}$ and mean annual precipitation between $500-650 \mathrm{~mm}$ ); a potato-growing area (luvisols, cambisols, up to $600 \mathrm{~m}$ a. s. $1 ., 6-8^{\circ} \mathrm{C} ; 600-800$ $\mathrm{mm}$ ); and a mountain area (cambisols, $>600 \mathrm{~m}$ a. s. $1 .,<6^{\circ} \mathrm{C}$, $>800 \mathrm{~mm}$ ). The results of climatic models based on the data acquired between 1981-2010 show that nearly $27 \%$ of the area of interest has a negative balance of water regime in the landscape, and that this share is expected to increase to $39 \%$ by 2040 (Czech Globe, 2021).

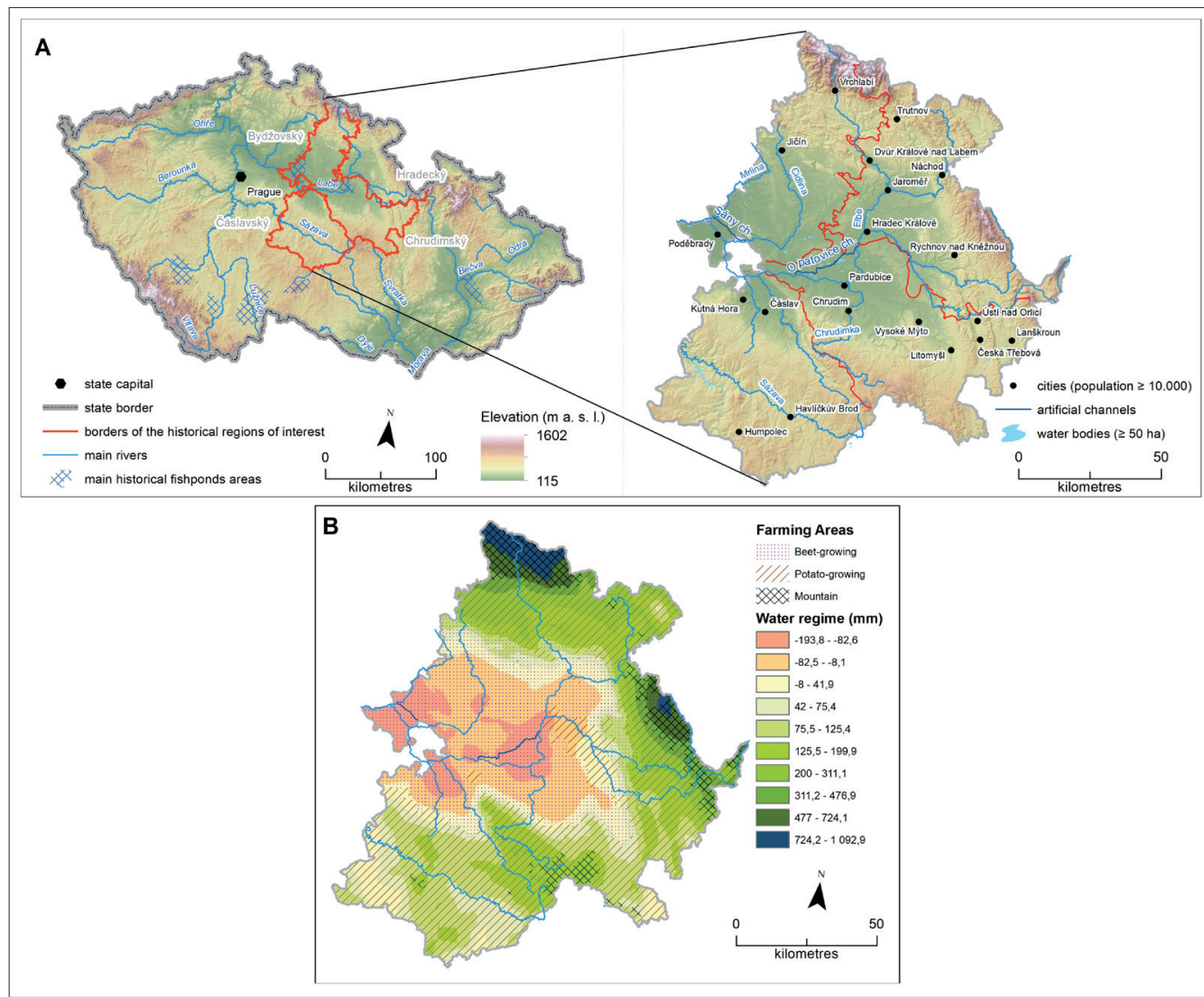

Fig. 2: Study area: A) Location of the study area within the Czech Republic (note: borders of the historical regions are based on the maps from the 1MS); B) Water regime (1981-2010); and Farming areas

Sources (for data): Arc ČR 500; Semotanová and Synek, 2007; CzechGlobe, 2021; ČÚZK, 2021 


\section{Data and methods}

\subsection{Historical maps}

The $1^{\text {st }}$ Military Survey (1MS) of the Habsburg Empire is the basic historical map source for our study. It was undertaken for military-strategic reasons and was completed during the reign of Joseph II (it is also known as the Josephian Survey). The Habsburg Monarchy was surveyed between the years 1764-1783. The Czech Lands, which belonged to the Monarchy, were surveyed in 17641768 on the scale of $1: 28,800$, and some map sheets were rectified between 1780-1783 (Zimová et al., 2006a). The survey utilised older enlarged Müller's maps of Bohemia and Moravia with astronomically determined geodetic points (Janata and Cajthaml, 2021), although the plotting itself was accomplished using the à la vue method through military engineers who rode horses on the landscape and took notes (Krejčí et al., 2009). Together with the maps, military engineers made a written description of the depicted areas (Vávrová and Šantrůčková, 2009). These written sources were not used for our study.

The absence of adequate cartographic procedures and the lack of a geodetic network had an impact on the positional deviation of the resulting maps (Zimová et al., 2006b). It is then rather problematic to follow the sequence of individual map sheets when processing a larger area and to maintain a uniform procedure in georeferencing. The entire area of the Habsburg Monarchy was newly georeferenced within the Arcanum Mapire project using the mathematical model Cassini-Soldner map projection for an unknown map grid of the original maps (Molnár and Timár, 2015). It results in a seamless layer of $1 \mathrm{MS}$ which is available in the map portal Mapire.eu and access can be bought for a fee via the Web Map Tiled Service (WMTS) for GIS software in the Web Mercator projection. The positional accuracy of this georeferenced layer varies. For the fifty selected ground control points, Janata and Cajthaml (2021) showed that the median of the positional deviation of this layer is about $250 \mathrm{~m}$, but the maximum deviations can reach $2,000 \mathrm{~m}$ in a few cases.

The second source of spatial information of the historical landscape is the $2^{\text {nd }}$ Military Survey (2MS) of the Habsburg Empire, which was created in the years 1836-1852 on an identical scale $(1: 28,800)$. This survey was based on more precise geodetic field methods and used a network of trigonometric points (Timár, 2009). The positional accuracy of this survey is very high, and the positional deviations are less than $50 \mathrm{~m}$ (Zimová, 2006b). We accessed the seamless georeferenced layer of the $2 \mathrm{MS}$ on the Mapire.eu portal.

\subsection{Spatial datasets}

Publicly available spatial data are used in this study: the GIS layer of water reservoirs (WR) from the Digital bases of water management data (DIBAVOD); the Digital Elevation Model (DEM); and the official regionalisation of farming areas (FA) of the Czech Republic (reflecting physical geographic conditions for agriculture production). The detailed attributes of each source are presented in Table 1. In addition to these sources, we have also used the outputs of two scientific projects: (i) Assessment of agricultural land in the areas of former fishpond systems with the aim of supporting the sustainable management of water and soil resources in the Czech Republic; and (ii) CzechAdapt System for Exchange of Information on Climate Change Impacts, Vulnerability and Adaptation Measures on the Territory of the Czech Republic. We acquired the GIS layer of Historical fishponds of the Czech Republic (HFCR) in the first one (i). This polygon layer contains vectorised manmade ponds from the 2MS, for the complete area of the Czech Republic. Ponds larger than 0.5 ha have an attribute about their existence or non-existence to present. This

\begin{tabular}{ll}
\hline Spatial dataset & Description \\
\hline Water reservoirs (WR) & Polygon layer; part of the \\
$\left(\right.$ A05 Vodní nádrže $\left.e^{*}\right)$ & DIBAVOD; based on the \\
& Fundamental Base of Geographic \\
& Data of the Czech Republic \\
& (ZABAGED $\left.{ }^{\mathrm{B}}\right)$, from the year 2010 \\
& on the scale of $1: 10,000$
\end{tabular}

Digital Elevation Model of the Czech Republic (DEM)

Farming areas (FA) (Výrobni oblasti a podoblasti katastrálních území)

Historical Fishponds of the Czech Republic (HFCR)

Changes in landscape water regime 1981-2010 (WReg)
Derived from Lidar data. Distributed in the raster format (cell size $50 \times 50 \mathrm{~m}$ ); part of the spatial data package ArcCR500 (version 3.3; 2016)

The official regionalisation of the territory of the Czech Republic reflects the agro-ecological conditions of the territory for agricultural production; distributed as an attribute table for all cadastral municipalities (last updated 2021)

Polygon layer of the historical fishponds; based on the $2^{\text {nd }}$ Military Survey (1836-1852); (last updated 2016)

Based on the AgriClim tool developed by CzechGlobe; raster dataset $($ cell size $=500 \times 500 \mathrm{~m})$

\section{Administrator/Source Access}

T. G. Masaryk Water Research Institute, Public Research www.dibavod.cz Institution (VÚV T.G.M.) (public source)

ArcDATA Prague Ltd. State Administration of Land Surveying and Cadastre (ČÚZK)

State Administration of Land Surveying and Cadastre (ČÚZK)

\section{Ministry of Agriculture} Palacký University Olomouc T. G. Masaryk Water Research Institute, Public Research Institution (VÚV T.G.M.)

Global Change Research Institute, CAS (CzechGlobe) https://www.arcdata.cz/ (public source)

https://www.cuzk.cz/ (public source)

https://heis.vuv.cz/ (data on demand)

https://www.klimatickazmena.cz/ en/?l=33

(data on demand) 
layer was finished in 2016 on the base of the georeferenced 2MS, which is accessible by the Czech National Geoportal via WMS.

From the CzechAdapt project (ii), we use the data for landscape water regimes from 1981 to 2010 . The resulting raster layers expressed the mean difference between annual sums of precipitation and reference evapotranspiration during the years. It is based on the calculation from AgriClim software, which was developed for calculating agroclimatic indicators (see Trnka et al., 2011). This software works with a database of meteorological elements in a daily step (maximum and minimum air temperatures, a sum of global solar radiation, precipitation totals, wind speed, and air humidity) for the current climate, which is based on measurements at individual stations throughout the Czech Republic. These values are interpolated to grids $(500 \times 500 \mathrm{~m})$ covering the Czech Republic, to which AgriClim is then applied. Its key components include the SoilClim model for calculating reference and actual evapotranspiration, moisture and soil temperature, and a description of the soil climate (Czech Globe, 2021).

\subsection{Data preparation and processing}

A layer of all water bodies found in the area of interest in the four historical regions was created as the first step using the software ArcMap 10.3 based on the 1MS (from WMTS provided by Mapire portal). The regions were recorded in the $1 \mathrm{MS}$. There were 7,796 objects in total. Three attributes were recorded for each object (pond): type (man-made or natural: following the Fairchild et al., 2013 methodology); area (hectares); and disappearance (dichotomous: yes: pond occurs only on the 1MS; no: pond occurs on the 1MS and $2 \mathrm{MS})$. The last attribute was studied using the visual comparison of the 1MS and 2MS in the portal Mapire (tool Synchronized view). Only man-made ponds were entered into further analyses: they were saved in the $1 \mathrm{MS}$ mp layer. Another 536 ponds were vectorised in the buffer zone of $2 \mathrm{~km}$ along the border of the area of interest for the needs of spatial analyses (see below). Furthermore, a point layer was created with the localities of the dams of former ponds, which were displayed in the $1 \mathrm{MS}$ within the area of interest.

For the basic statistical evaluation, the polygon layer of man-made ponds (1MS mp) was converted to the point layer (centroid for each pond; layer: 1MS_mpp), to which was consequently assigned the attributes of altitude from DEM and affiliation with Farming Areas (FA) (Tab. 2). The 1MS_mp layer through the ArcMap tool Kernel density layer ( with this setting: cell size $=550$; search radius $=6,500$ ) was used to assess the spatial concentration of ponds. The same process was applied to the HFCR layer for further comparison. Man-made ponds from the buffer zone also entered this analysis in order to avoid distortion of spatial analyses at the boundaries of the study area.
A grid of hexagons (area of one hexagon $=5 \mathrm{~km}^{2}$ ) was created for the entire territory to evaluate the development of man-made ponds in the landscape and its current water regime. For each hexagon, the areas (square metres) of manmade ponds from each source (1MS_mpp; HFCR; WR) were calculated using Hawth's Analysis Tools (Beyer, 2004) in ArcMap. Furthermore, for each hexagon, the mean value of water balance and altitude was calculated from the raster data WReg and DEM using the Zonal Statistics tool. This created a HEX layer with all the above attributes.

Data from the 1MS_mpp and HEX layer were then entered into statistical processing. The Mann-Whitney $\mathrm{U}$ test was used for bonds within the 1MS_mpp layer. The null hypothesis that all samples come from the same population (i.e. have the same median) was tested at a significance level of $\alpha=0.05$.

Concerning the second objective of the article, it is necessary to focus on identifying areas where data on the location of defunct historic ponds could serve to restore them. For this purpose, cluster analysis is primarily used to create different types of areas, depending on altitude and water balance, but also depending on the representation of water areas and their change over time. Cluster analysis was applied to the data from the HEX layer (with the hierarchical method and Euclidean distance setting). Ward's method was chosen as a criterion for clustering. The variables that entered the cluster analysis for each hexagon were the following: altitude, a sum of pond area from the 1MS_mp layer, a sum of the area from the WR layer, and mean water balance from the Wreg layer. For individual clusters, the hypothesis of concordance of medians of water balance in each hexagon was tested at a significance level $\alpha=0.05$. If this hypothesis was rejected, the methods of multiple comparisons were used to determine the differences between the individual pairs of clusters (again at the level of significance $\alpha=0.05$ ). The authors used nonparametric methods of hypothesis testing since conditions of data normality were not met.

\section{Results}

\subsection{The number of man-made ponds and their spatial distribution}

Some 7,796 ponds were identified in the studied area in the 1MS. Of those, 7,676 objects were identified as man-made ponds $(98.5 \%)$. The man-made ponds covered $22,828.72$ ha (i.e. $99.6 \%$ of the total area of all ponds). As can be seen in Figure 3, the largest proportion is for ponds with an area of up to 2 ha, of which there were nearly $85 \%$. The most significant coverage in the total area, however, was for 32 ponds with an area exceeding 100 ha. This number is only indicative with respect to the positional deviation of the $1 \mathrm{MS}$. It is evident from the spatial distribution of ponds that the highest number of man-made ponds were concentrated in the south part of the study area (Fig. 4a). Its terrain is

\begin{tabular}{|c|c|c|c|c|c|c|}
\hline \multirow{2}{*}{$\begin{array}{l}\text { Farming Area } \\
\text { (FA) }\end{array}$} & \multicolumn{2}{|c|}{ Sum of ponds } & \multicolumn{2}{|c|}{ Disappeared ponds* } & \multicolumn{2}{|c|}{ Non-disappeared ponds } \\
\hline & Abs. & Rel. (\%) & Abs. & Rel. (\%) & Abs. & Rel. $(\%)$ \\
\hline Beet-growing & 2,682 & 34.9 & 1,640 & 61.1 & 1,042 & 38.9 \\
\hline Potato-growing & 4,889 & 63.7 & 2,618 & 53.5 & 2,271 & 46.5 \\
\hline Mountain & 105 & 1.4 & 71 & 67.6 & 34 & 32.4 \\
\hline
\end{tabular}

Tab. 2: Disappeared man-made ponds from the $1 M S$ according to Farming Areas (FA) (Note: * ponds from the $1 M S$ that do not occur on the $2 \mathrm{MS}$ ). Source: authors' processing 
more rugged, hence allowing the construction of a higher number of ponds on smaller watercourses, commonly in the form of cascades where one pond followed from another. The sets of ponds covering the largest areas were located in the flatlands in the lower part of the Elbe tributaries
(Fig. 4c). Due to their location in the vicinity of large rivers, they were often built on artificial channels (Opatovice and Sány) which supplied them with water. This is also the case of the largest pond Blato, which covered nearly 910 ha in the 1MS_mp layer.

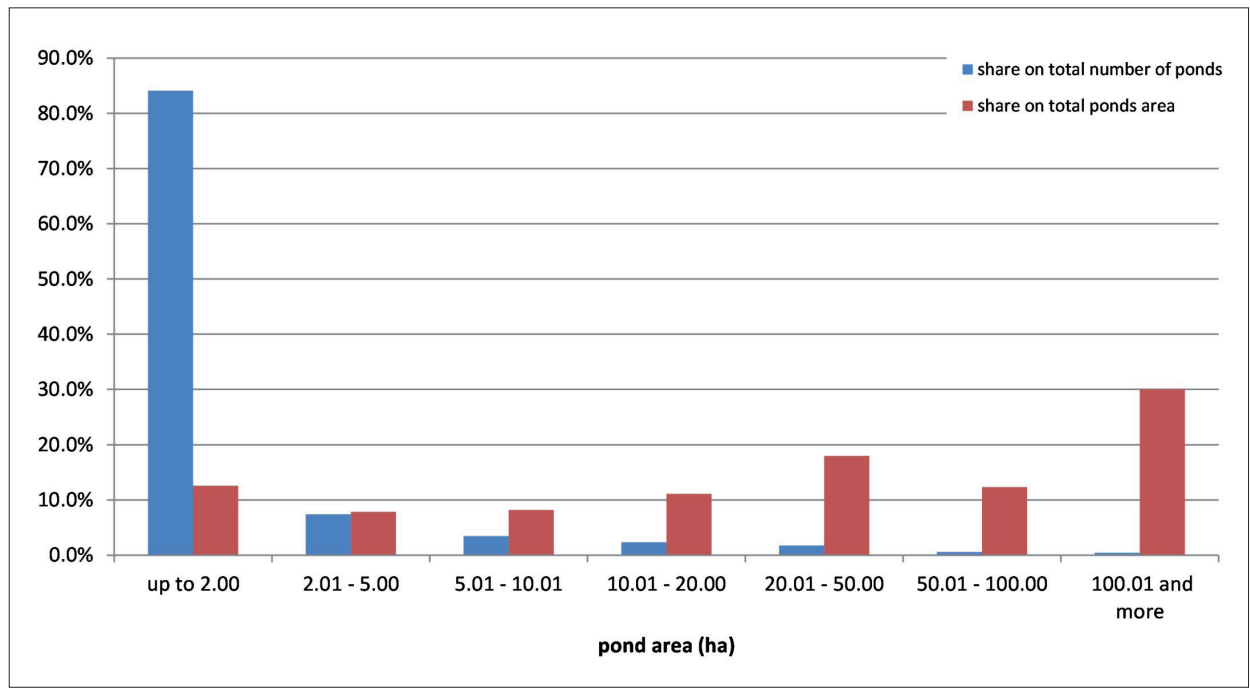

Fig. 3: Distribution of man-made ponds on the $1 M S$ by size categories Source: authors' processing
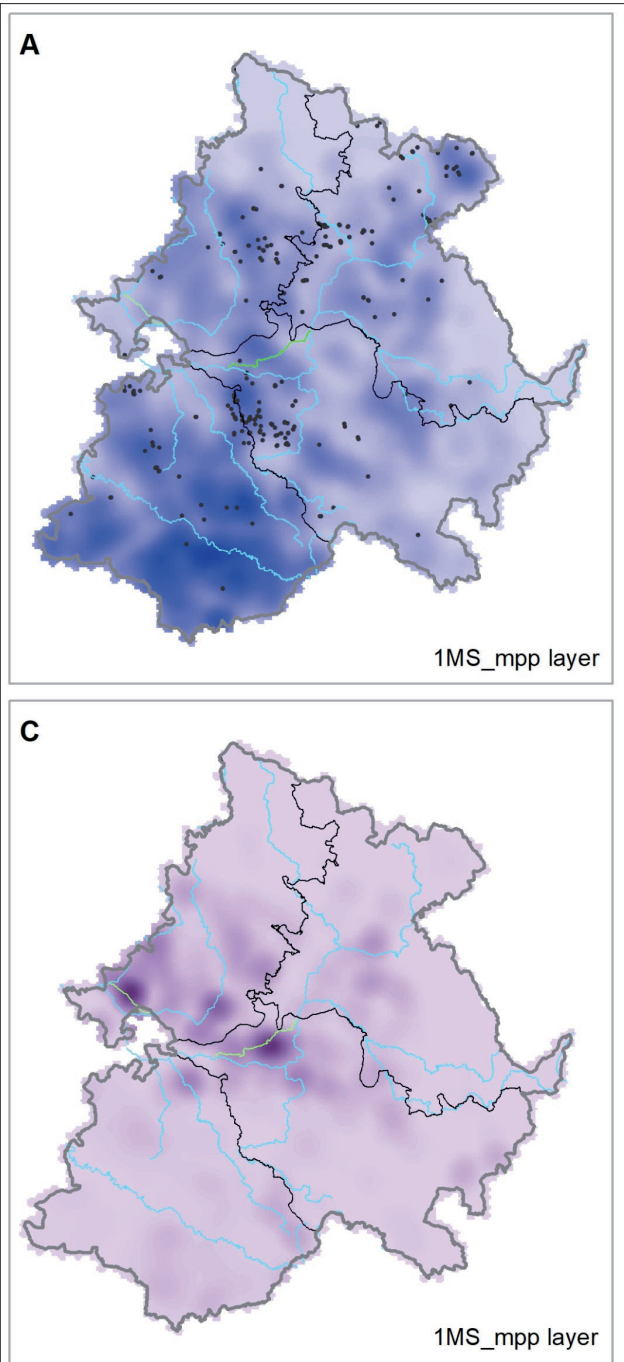

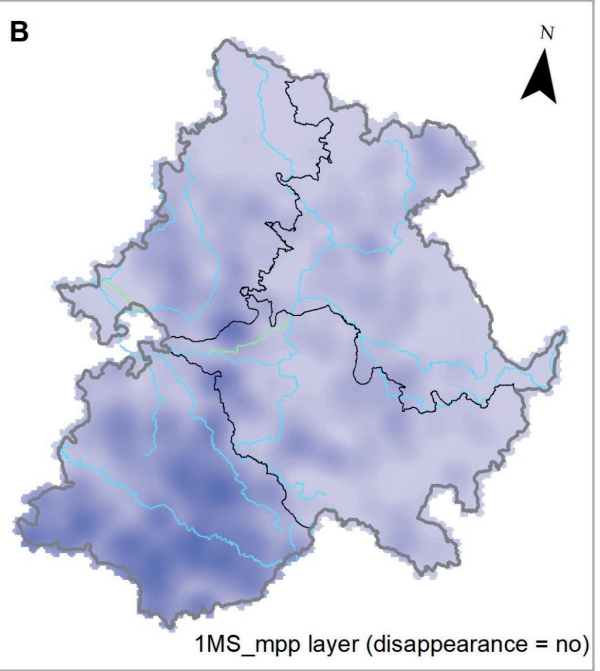

\section{Kernel density}

value

High : 2,71853

Low : 0

- borders of the historical regions

main rivers

artifical channels

- abandoned pond dams on the $1 \mathrm{MS}$

\section{Kernel density}

weighted by pond area

High : 27,0192

Low : 0

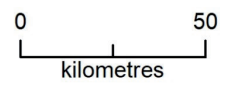

Fig. 4: Spatial distribution of man-made ponds based on the 1MS

Source: authors' processing 


\subsection{Disappearance rate and changes in the spatial distribution of man-made ponds}

Out of the total number of man-made ponds from the $1 \mathrm{MS}$, only 3,347 (43.6\%) were identified in the $2 \mathrm{MS}$. Thus, a significant number of them had disappeared during the wave of pond draining at the turn of the $18^{\text {th }}$ and $19^{\text {th }}$ centuries. Further, 265 relics of dams of fishponds were located in the 1MS maps, which had already been defunct in the period of the 1MS. Based on the Mann-Whitney test, the null hypothesis of equality of median values of the altitude of the former ponds and existing ponds $(p$-value $=0.00)$ is rejected. This means that those ponds located in lower altitudes ceased to exist more frequently. If only large ponds ( $>5 \mathrm{ha}$ ) were taken into account, then all those within $200 \mathrm{~m}$ were drained (Fig. 5). As shown in Table 2, the most fertile beet-growing area accounts for the largest proportion of lost ponds, but a significant proportion of ponds were also lost in the less fertile mountain farming area.

The number of man-made ponds recorded in the 1MS_mp layer, the layer of the historical fishponds (HFCR), and the current data for water reservoirs (WR) provides an interesting comparison. The current landscape register (12,163 objects in the study area) records the most water areas of all monitored periods, although this result is distorted by the character of the current data (see Discussion, below). Man-made ponds in the HFCR layer (4,639 objects in the study area) cover $60.5 \%$ of the number registered in the 1MS_mp layer. This number contains almost 1,300 more ponds than identified as not disappeared by comparing the $1 \mathrm{MS}$ and $2 \mathrm{MS}$ maps. This result means that fewer ponds were recorded in the 1MS map sheets in some areas than in the later $2 \mathrm{MS}$.

The spatial impact of pond drainage in the "first wave" is obvious in Figure 4b, it shows that many smaller ponds in the south and south-east part of the study area (former the Cáslav region) disappeared, as well as the drainage of large ponds in the fertile areas along the river Elbe.
The area of the ponds in the individual period from different spatial datasets (1MS_mpp layer; HFCR layer; WR layer) was compared using a hexagon grid (Fig. 6). The comparison of the periods demonstrates that the ratio of water areas of ponds plummeted between the end of the $18^{\text {th }}$ century and the middle of the $19^{\text {th }}$ century. On the other hand, there are a higher number of water areas in the landscape at present. Hexagons with a more dominant share of water area, however, are found in the places of modern large water dams and the relics of the original pond systems in the vicinity of the Opatovice channel.

\subsection{Cluster analysis}

The cluster analysis of the HEX layer $(n=2,604$ hexagons) was stopped at 5 clusters (A-E) (Tab. 3). A Kruskal-Wallis test $(p=0.00)$ with the null hypothesis that all samples come from the same population (i.e. have the same median) was carried out. Multiple comparisons have shown that there are significant statistical differences between the clusters except for the "C" cluster compared to the "B" and "E" clusters. The most frequent clusters "A" (50.3\% of the total number of hexagons) and "B" (34.7\%) are characterised by the highest median values of the average annual water regime and altitude. A smaller representation of pond areas in the 1MS was also identified in the "A" cluster, with a larger representation of the area of current ponds. On the other hand, the clusters " $\mathrm{D}$ " $(2.2 \%)$ and " $\mathrm{E}$ " (7.2\%) are characterised by negative median values of the average water regime, lower altitude, and a significant decrease in pond area (between 1MS and the present time - Tab. 3). If the results of the cluster analysis are projected in space (see Fig. 7a), it is evident that especially the lower areas with a negative water balance in the landscape are located in the most agriculturally fertile areas, where historically more areas of man-made ponds were concentrated than at present (Figs. 7b, 7c).

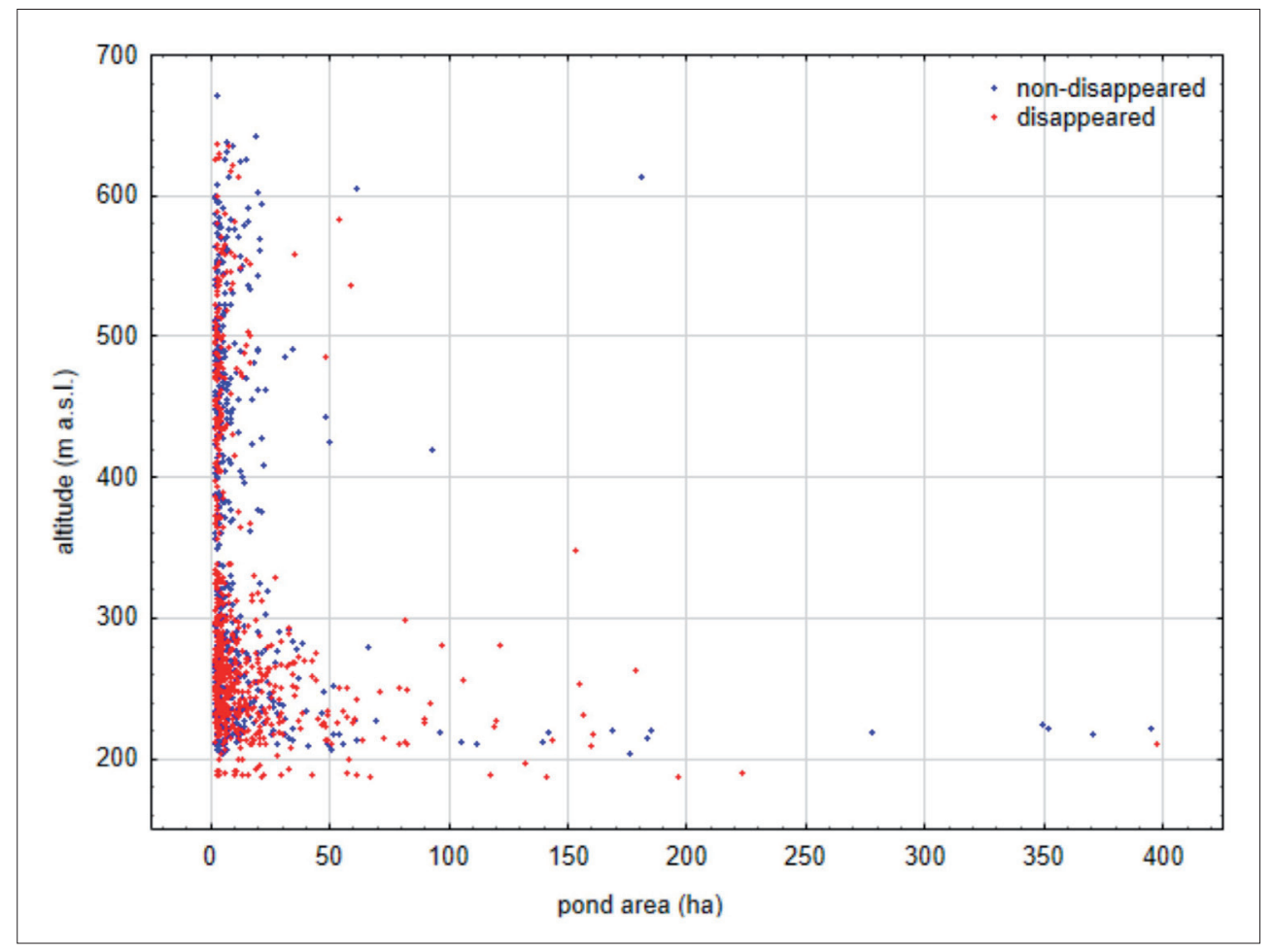

Fig. 5: Disappearance of man-made ponds (> 2 ha) according to altitude (Based on the data from a comparison of $1 M S$ and 2MS) (Note: For the clarity of the graph, the largest pond with an area of 910 ha was omitted) Source: authors' processing 


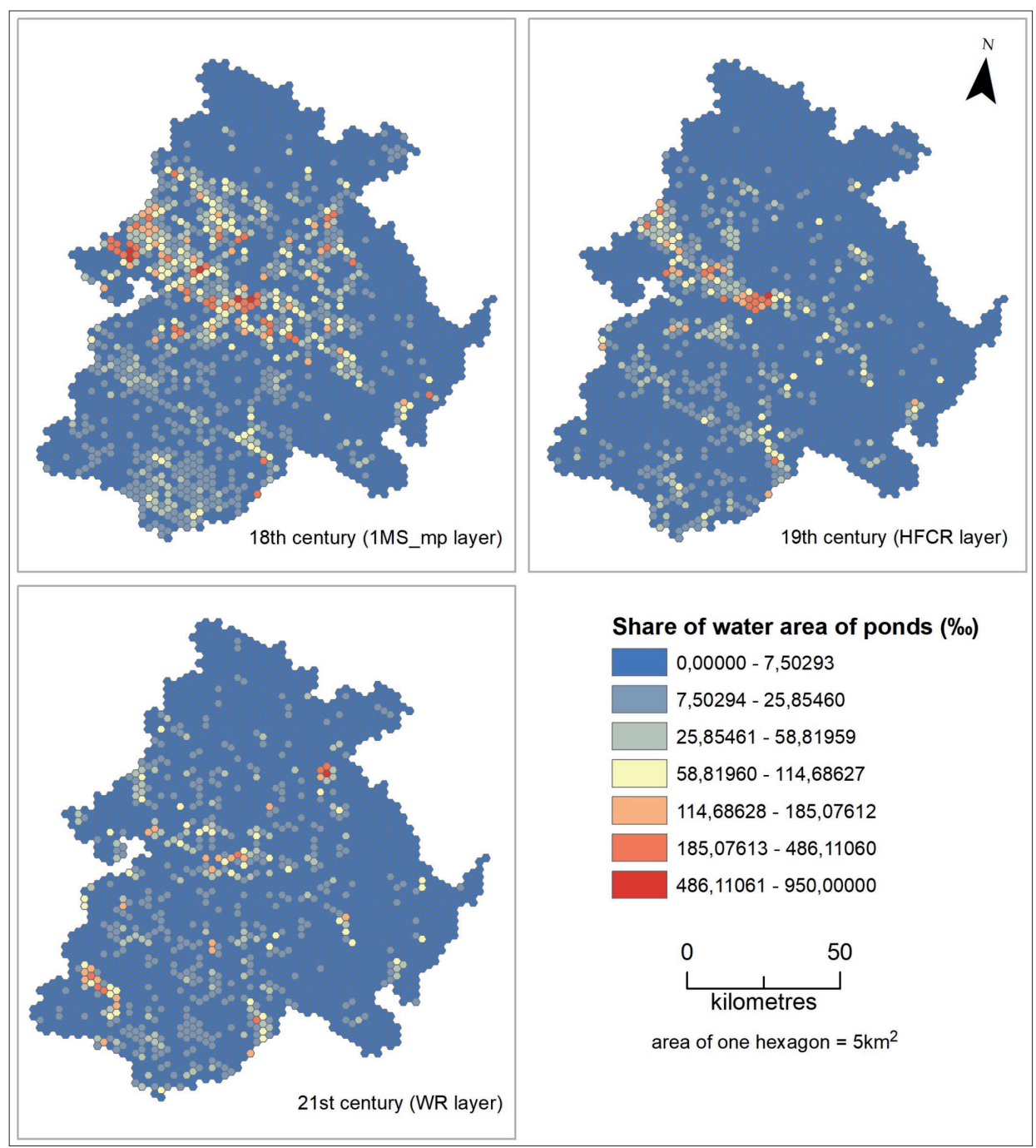

Fig. 6: Time-space comparison of the pond water areas. Sources: authors' processing based on the data from DIBAVOD (2010) and results from the project "Assessment of agricultural land in the areas of former fishpond systems with the aim of supporting the sustainable management of water and soil resources in the Czech Republic" (2016).

\section{Discussion}

\subsection{The disappearance of man-made ponds and changes in their spatial distribution}

The results show that the "first wave" of pond draining from the turn of the $18^{\text {th }}$ and $19^{\text {th }}$ centuries signified the end of $56 \%$ of man-made ponds recorded within our survey of the 1MS. The research of Pavelková et al. (2016) ascertained that more than $31 \%$ of historical ponds were drained from the middle of the $19^{\text {th }}$ century to the present day. Observing the results of both surveys, it follows that the first draining "wave" was more intensive. It is necessary, however, to consider the fact that our study only dealt with the area of four historical regions, while the study of Pavelková et al. (2016) covered the entire area of the Czech Republic, albeit only for ponds exceeding 0.5 ha. The gradual disappearance of ponds from the landscape was registered elsewhere in Europe as well. Boothby and Hull (1997) determined that $61 \%$ of ponds were drained in Cheshire County (UK) between 1870-1993. Jeffries (2012) reported nearly 40\% of drained ponds in Northumberland (UK) in the $19^{\text {th }}$ century. Similar to this situation, only $53 \%$ of the surfaces of the original medieval fishponds in the region of Dombes in France remain (Williams et al., 2006), and 59\% in the region of Rudy Wielkie in Poland (Jankowski, 2006).
These results confirm that the massive "wave" of draining man-made ponds at the turn of the $18^{\text {th }}$ century was concerned mostly with the lowland and fertile areas. It was caused by the character and size of the ponds, as well as the environment in which they were located. Johannes Dubravius (1486-1553) mentions in his classic manual about freshwater aquaculture De Pisces (About Fishponds), that ponds located in flat areas need only a moderate-size dam, which will then create a shallow pond of considerable size. Such ponds ceased to be economically profitable at the beginning of the $19^{\text {th }}$ century, however, and occupied significant areas of fertile soil in the fluvial plains. The massive draining of these ponds was aided by social reforms which abolished traditional serfdom in the Habsburg Monarchy in 1781, and which led to further interest of serfs in agricultural land. The ponds were drained, dewatered, and gradually turned mostly into fields and meadows, or less commonly into forests and built-up areas (Leglerová, 2019).

Another factor that aided this process was the boom of beetroot production (Daněk et al., 2015). It is significant that the current farming area, which stretches along the Elbe, is named after the sugar beet. It had been grown in the Czech Lands since 1770 with its boom connected with the expanding sugar production industry between 1810-1816 


\begin{tabular}{|c|c|c|c|c|c|c|c|}
\hline Variables & Cluster & $\mathbf{N}$ (ponds) & Median & Mean & Min. & Max. & $\begin{array}{l}\text { Standard } \\
\text { Deviation }\end{array}$ \\
\hline Water regime $(\mathrm{mm})$ & A & 1310 & 127 & 167 & -156 & 1,032 & 206 \\
\hline 1MS_mp layer (area $\left.\left[\mathrm{m}^{2}\right]\right)$ & & & 0 & 3,196 & 0 & 20,528 & 4,820 \\
\hline WR layer (area $\left.\left[\mathrm{m}^{2}\right]\right)$ & & & 2,005 & 5,053 & 0 & 39,696 & 7,567 \\
\hline Altitude (m a.s.l.) & & & 461 & 472 & 180 & 1,409 & 176 \\
\hline Water regime $(\mathrm{mm})$ & B & 903 & 64 & 53 & -169 & 798 & 94 \\
\hline 1MS_mp layer (area $\left.\left[\mathrm{m}^{2}\right]\right)$ & & & 41,526 & 51,330 & 0 & 161,004 & 36,661 \\
\hline WR layer (area $\left.\left[\mathrm{m}^{2}\right]\right)$ & & & 21,107 & 37,107 & 0 & 274,829 & 42,056 \\
\hline Altitude (m a.s.l.) & & & 411 & 401 & 182 & 886 & 129 \\
\hline Water regime $(\mathrm{mm})$ & $\mathrm{C}$ & 129 & 39 & 29 & -115 & 313 & 92 \\
\hline 1MS_mp layer (area $\left.\left[\mathrm{m}^{2}\right]\right)$ & & & 256,353 & 281,112 & 0 & $1,212,080$ & 249,611 \\
\hline WR layer (area $\left.\left[\mathrm{m}^{2}\right]\right)$ & & & 310,843 & 452,759 & 82,485 & $4,673,799$ & 519,846 \\
\hline Altitude (m a.s.l.) & & & 334 & 367 & 188 & 639 & 132 \\
\hline Water regime $(\mathrm{mm})$ & $\mathrm{D}$ & 56 & -87 & -76 & -130 & 74 & 45 \\
\hline 1MS_mp layer (area $\left.\left[\mathrm{m}^{2}\right]\right)$ & & & $1,313,535$ & $1,437,115$ & 738,973 & $3,717,478$ & 675,088 \\
\hline WR layer (area $\left.\left[\mathrm{m}^{2}\right]\right)$ & & & 9,002 & 73,109 & 0 & 762,529 & 162,747 \\
\hline Altitude (m a.s.l.) & & & 220 & 225 & 187 & 360 & 31 \\
\hline Water regime $(\mathrm{mm})$ & $\mathrm{E}$ & 206 & -32 & -8 & -156 & 314 & 86 \\
\hline 1MS_mp layer (area $\left[\mathrm{m}^{2}\right]$ ) & & & 264,874 & 324,032 & 151,529 & 763,799 & 159,154 \\
\hline WR layer (area $\left.\left[\mathrm{m}^{2}\right]\right)$ & & & 13,527 & 26,620 & 0 & 271,039 & 38,749 \\
\hline Altitude (m a.s.l.) & & & 256 & 303 & 188 & 657 & 118 \\
\hline
\end{tabular}

Tab. 3: Cluster characteristics. Source: authors' calculations

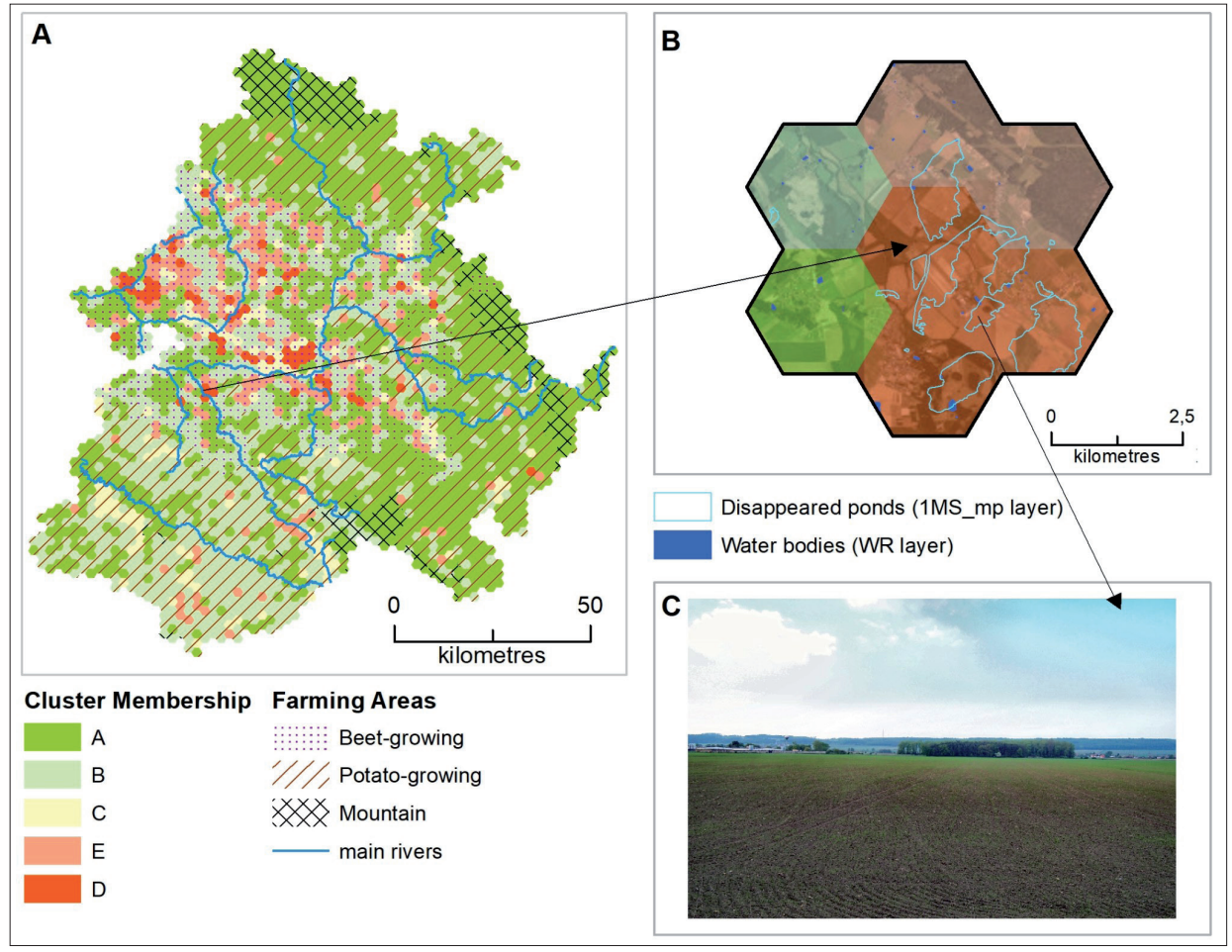

Fig. 7: Cluster Analysis results

Sources: DIBAVOD, 2010; CzechGlobe, 2021; ČUZZK, 2021; Photo by the authors

initiated by Napoleon's continental blockade (Dudek, 1979). This "sugar beet rush" caused a massive expansion of agricultural land along the Elbe, at the expense of ponds and floodplain meadows (Hellich, 1923). As a study by Sarapatka and Pavelková (2020) showed, the drainage of other ponds on the fertile soils of this area continued into the second half of the $19^{\text {th }}$ century. As can be seen from the recorded abandoned dams of the ponds in Figure 4a, however, the ponds were selectively drained before the middle of the $18^{\text {th }}$ century, that is, before agricultural intensification as well 
as the Enlightenment reforms. The reasons are as yet unknown, although these may have been ponds in a poor technical condition or those filled with sediments (Walter and Merritt, 2008), or those that were destroyed by flash floods (Elleder et al., 2020a; Jankowski, 2006).

On the other hand, the number of ponds which were drained in the areas at higher altitudes is interesting (the potatogrowing and mountain-farming areas). There was seemingly no reason for draining these ponds. First of all, they covered a small area and were found in cooler areas with less fertile wet soils which did not provide a quality base for arable crop farming. This was the reason many ponds (e.g. in the South Bohemia region) remain until the present day where they constitute a specific pond scape (Pokorný and Květ, 2018). The cause of the disappearance of small ponds in these highland regions can be found in their interconnection. This did not occur only in the framework of hydrology (same pond water supply), but also in the framework of the aquaculture itself. As early as 1547, following the instructions of Bishop Dubravius, the system of carp culture based on transferring fish to a different type of pond, according to their size, was established (Svanberg and Cios, 2014). The highland regions were typical for their great presence of breeding and fry ponds, which resisted fish fry and young fish to the chamber, and fattening ponds, which were placed in the lower-altitude areas. This disrupted the demand system. The ponds continued to be drained despite the growing price of fish fry. The maintenance of ponds was also very difficult, due to their location in deep hollows they faced sediment clogging during torrential rains (Hurt, 1960). This can also be demonstrated by studies of millponds which emphasise that a number of historical millponds faced rapid sediment accumulation and ceased to exist at the end of the $19^{\text {th }}$ century (Fairchild et al., 2013). Some man-made ponds thus disappeared naturally due to in-filling with sediments, the succession of vegetation and lack of maintenance. This may have happened to ponds that were used for logging needs in mountainous regions. Following the completion of logging or a change in log transport to lower-lying regions, these ponds were abandoned (Šádková and Jánský, 2020).

It is evident from the perspective of long-term development that the extent of pond areas was at its maximum at the end of the $18^{\text {th }}$ century, compared with the mid- $19^{\text {th }}$ century and the present. Currently, the number of ponds is higher, which may be due to several factors. Thus, in absolute numbers, we paradoxically register more bodies of water in the current landscape than at the end of the $18^{\text {th }}$ century. This phenomenon reflects two factors. The first is the refinement and improvement of cartographic work, where more manmade ponds appear in more recent maps, since especially smaller ponds were omitted in some historical surveys by mistake or intentionally (e.g. they were not a subject of the survey) (Jeffries, 2016). And secondly, the restoration and creation of new ponds were occurring simultaneously. Thus, as early as the end of the $19^{\text {th }}$ century, some ponds were restored for aquaculture (Francová et al., 2019), and others were created during the $20^{\text {th }}$ century for the needs of agriculture or later during the $21^{\text {st }}$ century, to support biodiversity in the landscape (Chabudziński et al., 2017; Fairchild et al. 2013; Jeffries, 2016;).

\subsection{Methodological issues}

Working with historical maps, it is always necessary to consider several uncertainties that may influence the interpretation of the results. According to Leyk et al. (2005), these uncertainties can be divided into three groups: a) production-oriented; b) transformation-oriented; and c) application-oriented. Therefore, we also have to consider the limitations of the $1 \mathrm{MS}$.

In the case of 'production-oriented', it is mainly how the $1 \mathrm{MS}$ was elaborated. The lack of geodetically adequate procedures led to misinterpretations and inaccuracies in locations, where a positional error in comparison to current maps may be as large as several hundreds of metres (Zimová et al., 2006b). This problem does not manifest itself in spatial analyses at smaller scales, as much as in the case of detailed case studies where other methods are necessary to determine the exact position of a pond (David and Černochová, 2020). It can also be assumed that plotting the water areas was probably complicated (especially with the larger ones) for surveying officers who plotted the individual landscape elements manually. Therefore, the acquired data on the size of ponds need to be understood only as indicative.

Another question is how carefully a specific area was plotted by individual surveyors (i.e. if perhaps some ponds might not have been omitted). As Prince (1959) states, despite uniform instructions, the course of historical surveying might have differed depending on their interpretations of individual surveyors. Approximately 30 surveyors worked in the Czech Lands (Šimůnek et al., 2014). It can be assumed that regarding the military purpose of surveying, ponds presented an important strategic element in the landscape, as evidenced in the written descriptions for the 1MS (Vávrová and Šantrůčková, 2009). Thus, the number of surveyed ponds should be quite accurate.

As Figure 8 suggests, however, if our layer of remaining ponds from the 1MS (1MS_mpp) is compared with the HFCR layer created based on the $2 \mathrm{MS}$, we find several areas where more ponds were surveyed in the 2MS than in the $1 \mathrm{MS}$. Leaving aside the possibility that some ponds may have been restored, it was probably an omission by the surveyors. This may be due to the terrain (deep valleys) creating difficulties to move on horseback, the concentration of a large number of ponds in a small area, and miscalculations.

From a current point of view, however, the somewhat trivial way of processing the $1 \mathrm{MS}$ also brings positives to the research issues. Above all, it is the symbolism of plotting the ponds, which were colored with a distinctive blue colour, and, in most cases, their dams were recorded using a line mark. Thus, artificial ponds can be distinguished from other ponds. All in all, the identification of ponds in the 1MS is easier than in the 2MS (see Fig. 9a), which struggles with faded colours, and the identification of ponds is commonly accomplished using indirect marks (Pavelková et al., 2016). Forejt et al. (2020) claimed that another limiting feature of maps may also be the lack of diachronic depth - they depict the dynamically evolving landscape only in a certain moment. In our case, some ponds were captured, which were in the process of draining and it was possible to identify them as a body of water, but at the same time, they had other uses (Fig. 9c).

The manner of processing the 1MS in GIS (mainly via georeferencing) introduces another possible distortion. We partially managed to deal with this problem using the seamless layer of the Mapire project, which was processed identically in the entire area. This aided in eliminating the issues with the possible connection of individual map sheets (Šimůnek et al., 2014) or the selection of different transformation methods while georeferencing (Baiocchi 


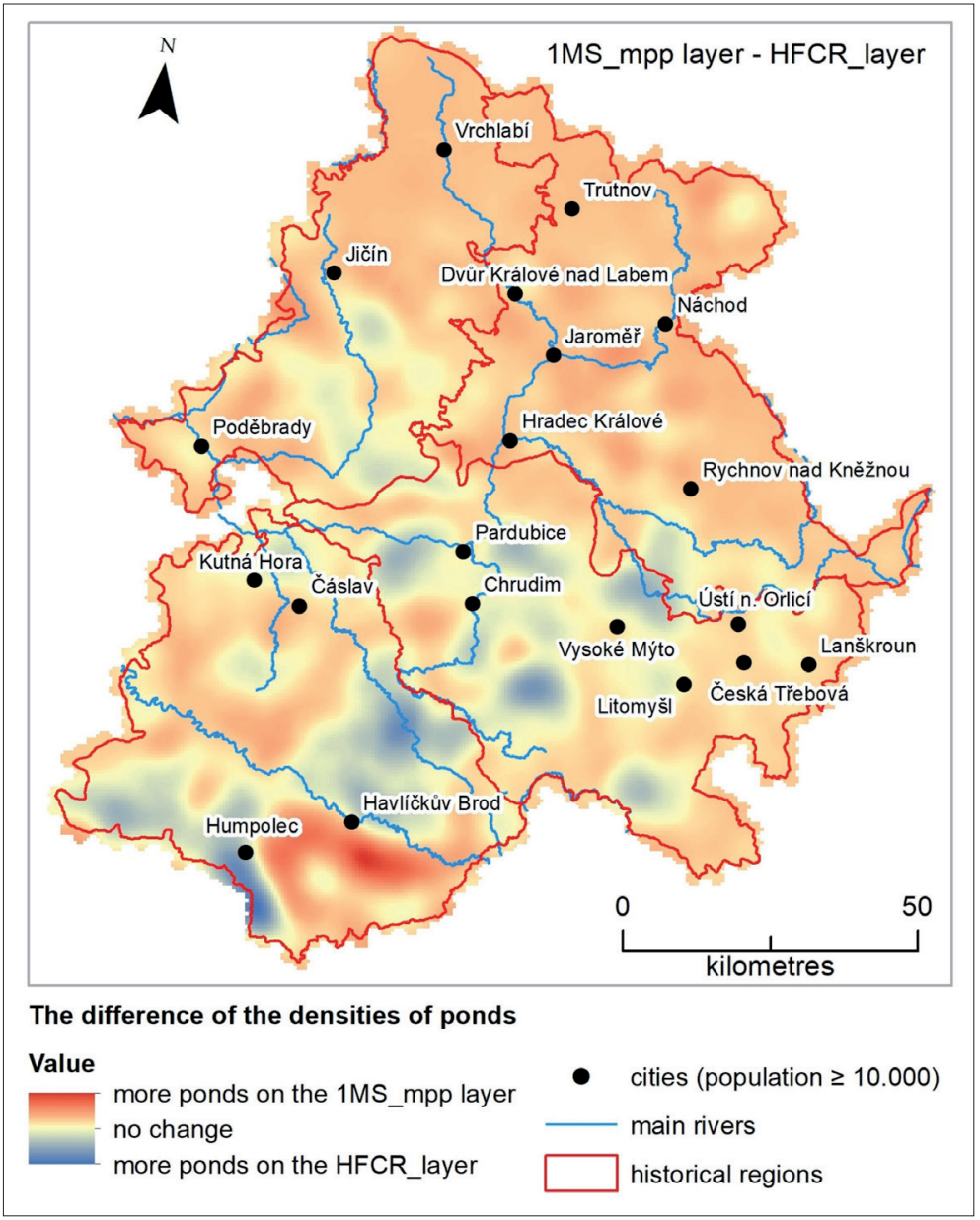

Fig. 8: Changes in pond density between different (cartographic) sources Source: authors' processing

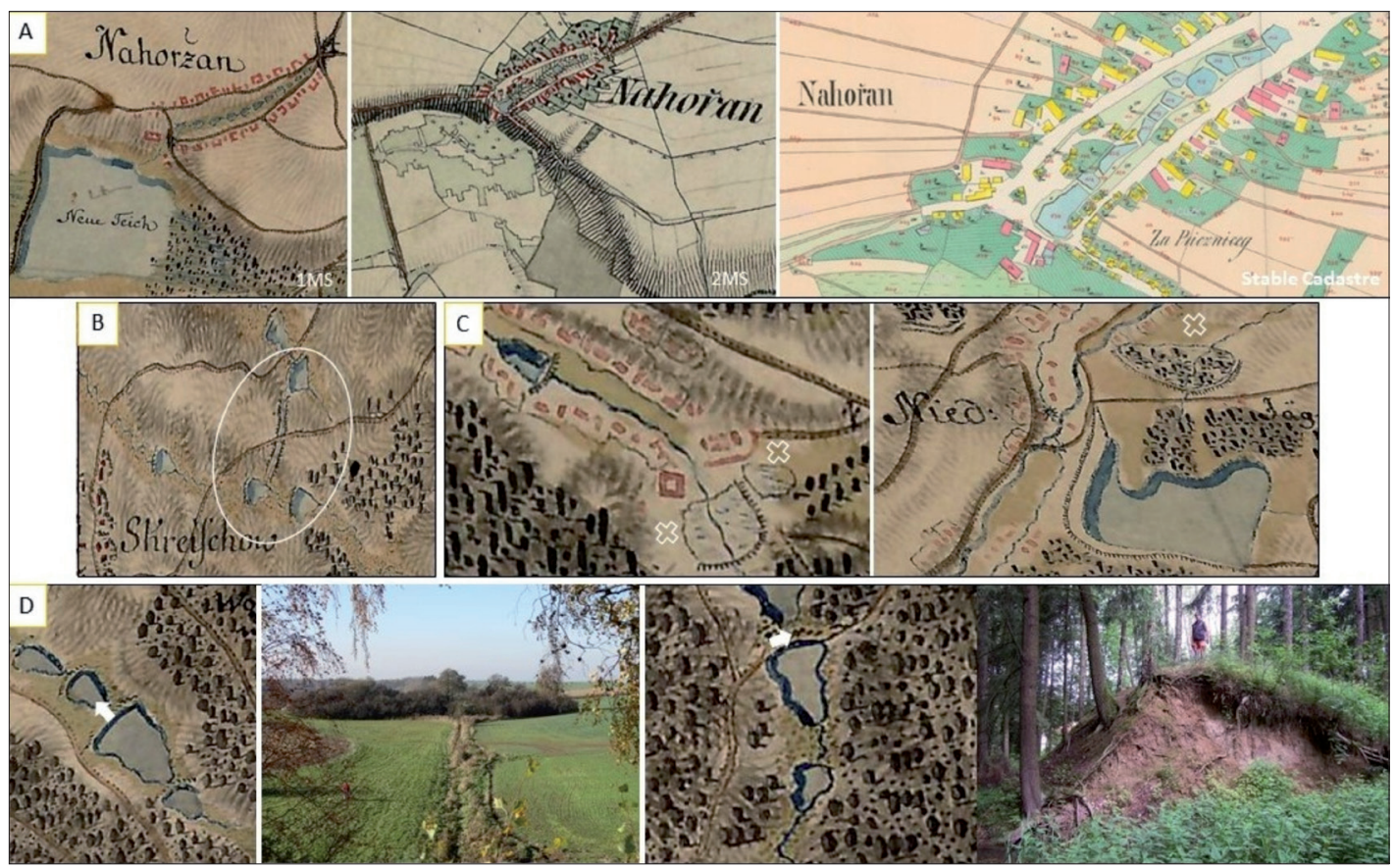

Fig. 9: Importance of the $1^{\text {st }}$ Military Survey for studying man-made ponds. (A) Comparison of map symbols for man-made ponds between $1^{\text {st }}$ and $2^{\text {nd }}$ Military Surveys and Stabile Cadastre; (B) Artificial pond feeder channel; (C) Man-made ponds on the $1^{\text {st }}$ Military Survey maps during the process of draining - marked with the white crosses; (D) Relics of the former ponds in the current landscape-former dams)

Sources: (C) ĆUZZK; (C) Austrian State Archives [Österreichisches Staatsarchiv] - all rights reserved (survey, z.B. Josephinische Landesaufnahme/First Military Survey), Mapire.eu; (C) Czech National Geoportal (CENIA); Photo by the authors 
et al., 2013). Despite that, the choice of an adequate transformation method at the local level should provide smaller positional deviations concerning the distribution and number of identical points. The issue of sheet connections and a greater degree of distortion was recorded, especially in the borders of historical regions of Bohemia and Moravia. Janata and Cajthaml (2021) proposed a new method of georeferencing of the 1MS map mosaic, with positional accuracy corresponding to Mapire.eu results, but with the minimum occurrence of substantial deformations of the map sheets. At present, however, their georeferenced maps are not yet available to other researchers.

This study is also limited by its manual processing in GIS, which may be susceptible to errors on the part of the researchers - whether be it due to a misinterpretation or an omission of the draft during vectorisation. Spatial analysis results can also be influenced by the Kernel Density tool's settings, where the cell size is only reflected in the visual quality of the resulting maps (Chainey, 2013), but the larger search radius can make the results smoother (Fotheringham et al., 2000, p. 45). We based our analysis on the recommended search radius by the ArcGIS Kernel Density tool.

\subsection{Implications for the applied use of the research results}

We have to deal with several problems concerning the possibility of using the data of the spatial distribution of ponds achieved from the 1MS - as combined with current data. Most of all, it is the earlier mentioned problem of positional accuracy, which can only be solved by a manual correction of the position of the ponds. Such a process is a very time-consuming with respect to the number of ponds (see Pavelková et al., 2016). Another issue is data consistency, which causes surprising problems, especially for the present. While it is possible to distinguish the natural and man-made ponds in the 1MS, the current data (WR layer) lacks such distinguishing attributes (although the layer is called "Water reservoirs"), and we register all types of stagnant water bodies regardless of origin or size. Another issue is scale, where the current data layers are detailed and elaborated on a scale of 1:10,000. Such issues impact the datasets. Compared to more recent and more accurate cartographic sources, e.g. the 2MS, they capture a larger number of ponds before the first wave of their draining. This provides the considerable potential to 'guess' the suitable location where it would be possible to renew ponds or other man-made reservoirs (David and Davidová, 2014; 2015; Šádková and Jánský, 2020), which is, in reality, occurring with the support of state subsidy programs (Rozkošný et al., 2020).

Pond restoration, a possible adaptation measure, can be expected to be in the interest of landscape management, especially with respect to the changing climate and its impact on the European landscape (the increased number of hot days, more frequent episodes of heavy rainfall, interspersed with longer periods of drought). Moreover, ponds and the history of their construction are known to the general public in the context of the Czech Republic, therefore they are often mentioned by political representatives as a tool to mitigate the future effects of drought (Ministry of Agriculture of the Czech Republic, 2019; Ministry of the Environment of the Czech Republic, 2020). Trantinová (2015) surveyed the local authorities of 134 small and medium-sized municipalities, which showed that $86 \%$ of municipal representatives consider ponds to be important landscape features in the municipality, and $77 \%$ would support the renewal of ponds in the municipality with sufficient funding. At the same time, $26 \%$ of the representatives of municipalities responded that they use old maps to obtain information about former ponds, and $47 \%$ are aware of former ponds within the municipality due to local knowledge. This could be promoted by many relics of former ponds in the rural as well as the urban landscape - abandoned dams (Fig. 9d), bank lines, terrain depressions, and former embankments (David and Černochová, 2020; Frajer et al., 2020; Rippon, 2004) or by local toponymy (Frajer and Fiedor, 2018).

Ponds will become an important topic, especially in fertile agricultural areas that face a future threat in the form of droughts. This does not mostly concern the restoration of large ponds in fertile areas (Fig. 7c), where it would be spatially impossible and where there are not sufficient water sources at present, but mostly small ponds whose restoration does not require extensive water management studies or expensive technologies. The results of our study show that it was these small ponds with areas up to two hectares that were represented most in the historical landscape. The restoration of ponds represents merely one of several measures for water retention in the landscape (Dzuráková et al., 2018), and must be accomplished with appropriate sensitivity and concern for local water management and ecological conditions.

Following the example of the government's program to build farm ponds in India, Kale (2017) stated that unrestrained construction of man-made ponds or their expansion can ultimately accelerate drought problems in the landscape - increase evapotranspiration and increase groundwater extraction in an effort to store as much water as possible. Looking at old maps, we obtain a picture of the landscape with a large number of man-made ponds, although we do not know how they coexisted in the landscape. Elleder et al. (2020b) stated that some large ponds may have been drained due to water shortages in drought episodes at the turn of the $18^{\text {th }}$ and $19^{\text {th }}$ centuries. Not only were they not economically viable without water, but they drained the necessary water from streams and rivers, which then disappeared due to intensive evapotranspiration. Some ponds may have had issues with an insufficient amount of water in the past and had to be fed by channels from other watersheds as historical maps show (Fig. 9b). Continuous maintenance and conservation of man-made ponds are also very important. As research by Juszak and Kędziora (2003) showed, many man-made ponds may be subject to severe anthropogenic pressure (landfilling, pollution from waste, sewage water, and agricultural activity) which degrades their ecological role.

\section{Conclusions}

In this study, we attempted to contribute to the debate on historical maps and their use in connection with GIS (Historical GIS) for solving questions related to historical and current landscapes. The first question was related to the extent of man-made ponds in the historical landscape. As was ascertained in the examples of four historical Bohemian regions, the $1^{\text {st }}$ Military Survey of the Habsburg Empire (1764-1783) shows that there were some 7,700 man-made ponds at the end of the $18^{\text {th }}$ century. The turn at the $18^{\text {th }}$ and $19^{\text {th }}$ centuries brought a significant reduction through the influence of political and economic changes (agricultural intensification, industrialisation), which had an impact on large ponds in fertile areas, as well as small ponds at higher altitudes. Thus, approximately one-half of man-made 
ponds disappeared. The landscape lost important elements regarding water retention and biodiversity. The pieces of information about disappeared ponds from the historical maps can be relevant even after several centuries and important for the present time (Canessa et al., 2017). In our case, the potential of the $1^{\text {st }}$ Military Survey for research of the historical extent of man-made ponds has proved worthy, and the information thus obtained can contribute as a basis, for example, to the debates on the restoration of water elements in the landscape, mainly in the agricultural areas with negative water balance. Our research pointed out the significance of historical maps in the study of the historical landscape where they may play an irreplaceable role (Fuchs et al., 2015). Although we deal with several methodological and interpretation limits in their processing, including problems of compatibility with current data, these historical sources cannot be understood only as contemporary works of art due to these shortcomings.

\section{Acknowledgments}

This study was supported by the grant of Palacky University Olomouc IGA_PrF_2021_027 "Landscape as a palimpsest of space and places". Miroslav Trnka contribution has been supported by "SustES - Adaptation strategies for sustainable ecosystem services and food security under adverse environmental conditions" (CZ.02.1.01/0.0/0.0/16_019/000 0797). The authors would like to express their thanks to all reviewers for their valuable remarks and recommendations.

\section{References:}

ANTROP, M. (2004): Landscape change and the urbanization process in Europe. Landscape and Urban Planning, 67: 9-26.

ARCČR (2016): Digital geographical database 1:500,000 ArcČR 500 Version 3.3 [cit. 29.09.2020]. ArcDATA Prague. Available at: http://download.arcdata.cz/data/ ArcCR_500-3.3-Popis-dat.pdf

BÁBEK, O., SEDLÁČEK, J., LENĎÁKOVÁ, Z., ELZNICOVÁ, J., TOLASZOVÁ, J., PACINA, J. (2021): Historical pond systems as long-term composite archives of anthropogenic contamination in the Vrchlice River, Czechia. Anthropocene, 33: 100283.

BAIOCCHI, V., LELO, K., MILONE, M. V., MORMILE, M. (2013): Accuracy of different georeferencing strategies on historical maps of Rome. Geographia Technica, 1(1): 0-16.

BARROS, V. R. et al. [eds.] (2014): Impacts, Adaptation, and Vulnerability. Part B: Regional Aspects. Working Group II Contribution of to the Fifth Assessment Report of the Intergovernmental Panel on Climate Change. Cambridge, Cambridge University Press.

BATEMAN, M. D., McHALE, K., BYNTUN, H. J., WILIAMS, N. (2020): Understanding historical coastal spit evolution: A case study from Spurn, East Yorkshire, UK. Earth surface processes and landforms, 45: 3670-3686.

BEYER, H. L. (2004): Hawth's analysis tools for ArcGIS [online]. Available at: www.spatialecology.com/htools

BIGGS, J., WILLIAMS, P., WHITFIELD, M., NICOLET, P., WEATHERBY, A. (2005): 15 years of pond assessment in Britain: results and lessons learned from the work of Pond Conservation. Aquatic conservation: Marine and freshwater ecosystems, 15: 693-714.
BJÖRK, S., POKORNÝ, J., HAUSER, V. (2010): Restoration of Lakes through Sediment Removal, with Case Studies from Lakes Trummen, Sweden and Vajgar, Czech Republic. In: Eiseltová, M. [ed.]: Restoration of Lakes, Streams, Floodplains, and Bogs in Europe: Principles and Case Studies (pp. 101-122). Springer, Dordrecht.

BOOTHBY, J., HULL, A. P. (1997): A census of ponds in Cheshire, North West England. Aquatic conservation: Marine and freshwater ecosystems, 7: 75-79.

BROŽA, V. et al. (2005): Přehrady Čech, Moravy a Slezska. Liberec, Knihy 555.

BRYKAŁA, D., PODGÓRSKI, Z. (2020): Evolution of landscapes influenced by watermills, based on examples from Northern Poland. Landscape and Urban Planning, 198: 1-15.

BÜNTGEN U., URBAN, O., KRUSIC, P. J., RYBNÍČEK, M., KOLÁ̌̌, T., KYNCL, T., AČ, T., KOŇASOVÁ, E., ČÁSLAVSKÝ, J., ESPER, J., WAGNER, S., SARER, M., TEGEL, W., DOBROVOLNÝ, P., CHERUBINI, P., REINIG, F., TRNKA, M. (2021): Recent European drought extremes beyond Common Era background variability. Nature Geoscience, 14(4): 190-196.

BURGIN, S., FRANKLIN, M. J., HULL, L. (2016): Wetland loss in the transition to urbanisation: a case study from Western Sydney, Australia. Wetlands, 36(6): 985-994.

CANESSA, M., MONTEFALCONE, M., BAVESTRELLO, G., POVERO, P., COPPO, S., MORRI, C., BIANCHI, C. N. (2017): Fishery maps contain approximate but useful information for inferring the distribution of marine habitats of conservation interest. Estuarine, Coastal and Shelf Science, 187(5): 74-83.

CÉRÉGHINO, R., BIGGS, J., OERTLI, B., DECLERCK, S. (2008): The ecology of European ponds: defining the characteristics of a neglected freshwater habitat. Hydrobiologia, 597: 1-6.

CHABUDZIŃSKI, Ł., SZULC, D., BRZEZIŃSKAWÓJCIK, T., MICHALCZYK, Z. (2017): Changes in the location and function of small water bodies in the upper Sanna River catchment-case study (SE Poland). Landscape Research, 43(1): 112-123.

CHAINEY, S. P. (2013): Examining the influence of cell size and bandwidth size on kernel density estimation crime hotspot maps for predicting spatial patterns of crime. Bulletin of the Geographical Society of Liege, 60: 7-19.

CHEN, W., HE, B., NOVER, D., LU, H., LIU, J., CHEN, W. (2019): Farm ponds in southern China: Challenges and solutions for conserving a neglected wetland ecosystem. Science of the Total Environment, 659: 1322-1334.

CHIANG, Y.Y., DUAN, W., LEYK, S., UHL, J. H., KNOBLOCK, C.A. (2020). Using historical maps in scientific studies: Applications, challenges, and best practices. Berlin, Springer.

CURADO, N. HARTEL, T., ARNTZEN, J. W. (2011): Amphibian pond loss as a function of landscape change - A case study over three decades in an agricultural area of northern France. Biological Conservation, 144(5): 1610-1618.

CZECH GLOBE (2021): Changes in a landscape water regime_Norway_CZE [online]. Available at: https://www. klimatickazmena.cz/cs/?l=33 
ČÚZK (2021): Výrobní oblasti a podoblasti katastrálních území [online]. Available at: https://www.cuzk.cz/ Katastr-nemovitosti/Poskytovani-udaju-z-KN/CiselnikyISKN/Ciselniky-k-mape/Vyrobni-oblasti-a-podoblastikatastralnich-uzemi.aspx

DANĚKK T., KILIÁNOVÁ H., BRUS J., PECHANEC V., OPRŠAL, Z. (2015): Development of Sugar Industry in Haná Region in $19^{\text {th }}$ Century and its Impact on Landscape Character. Listy Cukrovarnicke a Reparske, 131(4): 146-149.

DAVID, V., ČERNOCHOVÁ, K. (2020): Identification of ponds in the Blanice catchment area on maps of 1 st Austrian Military Survey. Vodohospodářské technickoekonomické informace, 62(1): 32-37.

DAVID, V., DAVIDOVÁ, T. (2015): Analysis of Available Retention Volume in Extinct Ponds - Case Study for Blanice River Catchment. Agriculture and Agricultural Science Procedia, 4: 79-87.

DE BIE, T., DECLERCK, S., MARTENS, K., DE MEESTER, L. BRENDONCK, L. (2008): A comparative analysis of cladoceran communities from different water body types: patterns in community composition and diversity. Hydrobiologia, 597(1): 19-27.

DE MEESTER, L., DECLERCK, S., STOKS, R., LOUETTE, G., VAN DE MEUTTER, F., DE BIE, T., MICHELS, E., BRENDONCK, L. (2005): Ponds and pools as model systems in conservation biology, ecology and evolutionary biology. Aquatic Conservation: Marine and freshwater ecosystems, 15(6): 715-25.

DEMEK, J., MACKOVČIN, P., SLAVÍK, P. (2012): Spatial and temporal trends in land-use changes of Central European landscapes in the past 170 years: A case study from the south-eastern part of the Czech Republic. Moravian Geographical Reports, 20(3): 2-21.

Digital Base of Water Management Data (DIBAVOD) (2010): Layer A_05 Water reservoirs [online]. Available at: https://www.dibavod.cz/index.php?id=27

DUDEK, F. (1979): Vývoj cukrovarnického průmyslu v českých zemích do roku 1872. Praha, Academia.

DZURÁKOVÁ, M., ŠTĚPÁNKOVÁ, P., LEVITUS, V. (2018): Katalog přírodě blízkých opatření pro zadržení vody $\mathrm{v}$ krajině a jeho uplatnění ve webové mapové aplikaci pro veřejnost. Vodohospodářské technicko-ekonomické informace, 60(5): 6-11.

ELLEDER, L., KREJČÍ, J., ŠÍROVÁ, J. (2020a): The 1714 flash flood in the Bohemian-Moravian Highlands Reconstructing a Catastrophe. Quaternary International, 538: 14-28.

ELLEDER, L., ŠÍROVÁ, J., DAVID, V., KAŠPÁREK, L., KLETETSCHKA, G., DRAGOUN, Z. (2020b): Growth and decline of fishery in Poděbrady and Nymburk estates from the point of view of historical hydrology. Vodohospodářské technicko-ekonomické informace, 1: $18-31$.

FACCINI, F., GIARDINO, M., PALIAGA, G., BRANDOLINI, P. (2020): Urban geomorphology of Genoa old city (Italy). Journal of Maps, 1-14.

FAIRCHILD, G. W., ROBINSON, C., BRAINARD, A. S., COUTU, G. W. (2013): Historical changes in the distribution and abundance of constructed ponds in response to changing population density and land use. Landscape Research, 38(5): 593-606.

FOREJT, M., DOLEJŠ, M., ZACHAROVÁ, J., RAŠKA, P. (2020): Quantifying inconsistencies in old cadastral maps and their impact on land-use reconstructions. Journal of Land Use Science, 15(4): 570-584.

FOTHERINGHAM, S., BRUNSDON, C., CHARLTON, M. (2000): Quantitative geography. Perspectives on Spatial Data analysis. London, Sage.

FRAJER, J. (2019): Josephian cadastre as a source of geographic information on historical landscapes. Geografie, 124(3): 315-339.

FRAJER, J., FIEDOR, D. (2018): Discovering extinct water bodies in the landscape of Central Europe using toponymic GIS. Moravian Geographical Reports, 26(2): 121-134.

FRAJER, J., PAVELKOVÁ, R., LÉTAL, A., KOPP, J. (2020): Relics and transformation of former ponds in the urban environment of the historical region of Bohemia (Czech Republic). Journal of Maps, 1-11.

FRANCOVÁ, K, ŠUMBEROVÁ, K., JANAUER, G. A., ADÁMEK, Z. (2019): Effects of fish farming on macrophytes in temperate carp ponds. Aquaculture International, 27: 413-436.

FUCHS， R., VERBURG， P. H., CLEVERS， J. G. P. W., HEROLD, M. (2015): The potential of old maps and encyclopaedias for reconstructing historic European land cover/use change. Applied Geography, 59: 43-55.

GREGORY, I. N., GEDDES, A. (2014): From historical GIS to spatial humanities: Deepening scholarship and broadening technology. In: Gregory, I. N., Geddes, A. [eds.]: Toward Spatial Humanities (pp. 9-19). Indiana University Press.

HAASE, D., WALZ, U., NEUBERT, M., ROSENBERG, M. (2007): Changes to Central European landscapes Analysing historical maps to approach current environmental issues, examples from Saxony, Central Germany. Land Use Policy, 24: 248-263.

HAVLÍČEK, M., PAVELKOVÁ, R., FRAJER, J., SKOKANOVÁ, H. (2014): The Long-Term Development of Water Bodies in the Context of Land Use: The Case of the Kyjovka and Trkmanka River Basins (Czech Republic). Moravian Geographical Reports, 22(4): 39-50.

HELLICH, J. (1923): Př́ispěvek k podobě zaniklých osad na Poděbradsku. Praha, Rodinné tiskárny v Praze.

HOFFMANN, R. (2002): Carp, cods and connections: new fisheries in the medieval European economy and environment. In: Henninger-Voss, M. J. [ed.]: Animals in human histories: the mirror of nature and culture (pp. 3-55). Rochester, NY, University of Rochester Press.

HURST, D., DAFFERN, N., GRIFFIN, L., HEAD, K., MANN, A., PEARSON, E., WARMAN, S. (2016): A Roman Pond at Wyre Piddle, Worcestershire, with a Brief Survey of Ponds in Roman Britain. Britannia, 47: 169-191.

HURT, R. (1960): Dějiny rybníkářství na Moravě a ve Slezsku I. a II. díl. Opava, Krajské nakladatelství v Opavě.

IGNATIUS, A., RASMUSSEN, T. C. (2016): Small reservoir effects on headwater water quality in the rural-urban fringe, Georgie Piedmont, USA. Journal of Hydrology: Regional Studies, 8: 145-161. 
JANATA, T., CAJTHAML, J. (2021): Georeferencing of MultiSheet Maps Based on Least Squares with ConstraintsFirst Military Mapping Survey Maps in the Area of Czechia. Applied Sciences, 11(1): 299.

JANSKÝ, B., ŠOBR, M. a kol. (2003): Jezera České republiky. Praha, Katedra fyzické geografie a geoekologie na PřFUK v Praze.

JANKOWSKI, G. (2006): Changes in time and space of pond farming in the area of Rudy Wielkie (Poland). Moravian Geographical Reports, 14(3): 19-25.

JEFFRIES, M. J. (2012): Ponds and the importance of their history: an audit of pond numbers, turnover and the relationship between the origins of ponds and their contemporary plant communities in south-east Northumberland, UK. Hydrobiologia, 689: 11-21.

JEFFRIES, M. J. (2016): Flood, drought and the inter-annual variation to the number and size of ponds and small wetlands in an English lowland landscape over three years of weather extremes. Hydrobiologia, 768(1): 255-272.

JOHNSTON, C. A. (2015): Fate of 150 Year Old Beaver Ponds in the Laurentian Great Lakes Region. Wetlands, 35: 1013-1019.

JUSZCZAK, R., KĘDZIORA, A., LEŚNY, J., OLEJNIK, J. (2007): Assessment of Water Retention Capacity of Small Ponds in Wyskoć Agricultural-Forest Catchment in Western Poland. Polish Journal of Environmental Studies, 16(5): 685-695.

JUSZCZAK, R., KĘDZIORA, A. (2003): Threats to and deterioration of small water reservoirs located within Wyskoć catchment. Polish Journal of Environmental Studies, 12(5): 567-573.

JU゚VA, K., HRABAL, A., PUSTĚJOVSKÝ, R. (1980): Malé vodní nádrže. Praha, SZN.

KAIM, D., TACZANOWSKI, J., SZWAGRZYK, M., OSTAFIN, K. (2020): Railway network of Galicia and Austrian Silesia (1847-1914). Journal of Maps, 16(1): 132-137.

KALE, E. (2017): Problematic uses and practices of farm ponds in Maharashtra. Economic \& Political Weekly, 52(3): 20-22.

KNOWLES, A. K. (2002): Past time, past place: GIS for history. Redlands, California, ESRI Press.

KOPP, J., FRAJER, J., PAVELKOVÁ, R. (2015): Driving Forces of the Development of Suburban Landscape A Case Study of the Sulkov Site West of Pilsen. Quaestiones Geographicae, 34(3): 51-64.

KREJČÍ, J., MIKŠOVSKÝ, M., ZIMOVÁ, R. (2009): Possible relation between the Müllers Map of Bohemia and the First Military Survey - A case study of the Kladno region. Acta geodaetica et geophysica Hungarica, 44(1): 39-48.

LANGTON, T. (1985): The London pond survey. Oryx, 19(3): 163-166.

LEGLEROVÁ, A. (2019): History and present state of the landscape of the former fish pond system in the drainage basin of the Opatovický kanál channel (Central and Eastern Bohemia). Master Thesis, Prague, Charles University.

LEYK. S., BOESCH, R., WEIBEL, R. (2005): A Conceptual Framework for Uncertainty Investigation in Map-based Land Cover Change Modelling. Transactions in GIS, 9(3): 291-322.
LHOTSKÝ, R. (2010): The role of historical fishpond systems during recent flood events. Journal of Water and Land Development. 14: 49-65.

LOCHMAN, Z. (1970): The Opatovice channel and its historico-geographical development. Sborník Československé společnosti zeměpisné, 75(3): 219-233.

LÖFLLER, H. (2003): The Origin of Lake Basins. In: O’Sullivan, P. E., Reynolds, C.S. [eds.]: The Lakes Handbook: Limnology and Limnetic Ecology (pp. 8-60). Wiley: London.

LUSK, S. (2015): Rybníky a ostatní malé vodní nádrže v krajině - význam a funkce. In: Pokorný, J., Zykmund, A., Mareš, J. ... [eds.]: České rybníky a rybářství ve 20. století (pp. 15-35). České Budějovice, Rybářské sdružení České republiky.

MACTAGGART, B., BAUER, J., GOLDNEY, D. (2007): When History May Lead us Astray: using historical documents to reconstruct swampy meadows/chains of ponds in the New South Wales Central Tablelands, Australia. Australian Geographer, 38 (2): 233-252.

MARIGNANI, M., ROCCHINI, D., TORRI, D., CHIARUCCI, A., MACCHERINI, S. (2008): Planning restoration in a cultural landscape in Italy using an object-based approach and historical analysis. Landscape and urban planning, 84(1): 28-37.

MOLNÁR, G., TIMÁR, G. (2015): Inversion application in cartography: Estimation of the parameters of the best fitting Cassini-projections of the First Habsburg Military Survey. Geosciences and Engineering, 4(6): 36-44.

MOSS, B. (2017): Ponds and small lakes: Microorganisms and freshwater ecology. Exeter, Pelagic Publishing Ltd.

MUIR, R. (2004): Landscape Encyclopaedia: A reference guide to the Historic Landscape. Windgather Press.

OERTLI, B., AUDERSET JOYE, D., CASTELLA, E., JUGE, R., CAMBIN, D., LACHAVANNE, J. (2002): Does size matter? The relationship between pond area and biodiversity. Biological Conservation, 104(1): 59-70.

PAVELKOVÁ, R., FRAJER, J., NETOPIL, P. a kol. (2014): Historické rybníky České republiky: Srovnání současnosti se stavem v 2. polovině 19. století. Praha, Výzkumný ústav vodohospodářský T. G. M.

PAVELKOVÁ, R., FRAJER, J., HAVLÍČEK, M., NETOPIL， P., ROZKOŠNÝ, M., DAVID, V., DZURÁKOVÁ, M., ŠARAPATKA, B. (2016): Historical ponds of the Czech Republic: an example of the interpretation of historic maps. Journal of Maps, 12(sup1): 551-559.

PINDOZZI, S., CERVELLI, E., CAPOLUPO, A., OKELLO, C., BOCCIA, L. (2016): Using historical maps to analyze two hundred years of land cover changes: case study of Sorrento peninsula (south Italy), Cartography and Geographic Information Science, 43(3): 250-265.

PODOBNIKAR, T. (2010). Historical maps of Ljubljana for GIS applications. Acta geodaetica et geophysica Hungarica, 45(1): 80-88.

POKORNÝ, J., HAUSER, V. (2002): The restoration of fish ponds in agricultural landscapes. Ecological engineering, 18: 555-574.

POKORNÝ, J., KVĚT, J. (2018): Fishponds of the Czech Republic. In: Finlayson, C. M., Milton, G. R., 
Prentice, R. C., Davidson, N. C. [eds.]: The Wetland Book II: Distribution, description, and conservation (pp. 469485). Dordrecht, Springer.

POTUŽÁK, J., DURAS, J., DROZD, B. (2016): Mass balance of fishponds: Are they source or sinks of phosphorus? Aquaculture International, 24(6): 1725-1745.

PRINCE, H. C. (1959): The Tithe Surveys of the MidNineteenth Century. The Agricultural History Review, 7(1): 14-26.

PRINCE, H. C. (1962): Pits and ponds in Norfolk. Erdkunde, 16(1): 10-31.

REES, S. E. (1997): The historical and cultural importance of ponds and small lakes in Wales, UK. Aquatic Conservation: Marine and Freshwater Ecosystems, 7(2): 133-139.

RENWICK, W. H., SMITH, S. V., BARTLEY, J. D., BUDDEMEIER, R. W. (2005): The role of impoundments in the sediment budget of the conterminous United States United States. Geomorphology, 71(1-2): 99-111.

RIPPON, S. (2004): Historic Landscape Analysis: Deciphering the Countryside. London, Council for British Archaeology.

ROZKOŠNÝ, M., DZURÁKOVÁ, M., PAVELKOVÁ, R., DAVID, V., HUDCOVÁ, H., NETOPIL, P. (2020): Small Water Reservoirs, Ponds and Wetlands Restoration at the Abandoned Pond Areas. In: Zelenakova, M., Fialova, J., Negm, A. M. [eds.]: Assessment and Protection of Water Resources in the Czech Republic (pp. 127-146). Cham, Springer.

RUGGIERO, A., CÉRÉGHINO, R., FIGUEROLA, J., MARTY, P., ANGÉLIBERT, S. (2008): Farm ponds make a contribution to the biodiversity of aquatic insects in a French agricultural landscape. Comptes Rendus Biologies, 331(4): 298-308.

RU゚ŽIČKA, K. (1954): Z historie rybníkářství. Vodní hospodářství, 12: 365-367.

SEMOTANOVÁ, E., SYNEK, J. [eds.] (2007): Ottův historický Atlas Česko. Praha, Ottovo nakladatelství

SKALOŠ, J., WEBER, M., LIPSKÝ, Z., TRPÁKOVÁ, I., ŠANTRƯČKOVÁ, M., UHLÍŘOVÁ, L., KUKLA, P. (2011): Using old military survey maps and orthophotograph maps to analyse long-term land cover changes - Case study (Czech Republic). Applied Geography, 31: 426-438.

SKALOŠ, J., RICHTER, P., KEKEN Z. (2017): Changes and trajectories of wetlands in the lowland landscape of the Czech Republic. Ecological Engineering, 108: 435-445.

SMITH, S. V., RENWICK, W. H., BARTLEY, J. D., BUDDEMEIER, R.W. (2002): Distribution and significance of small, artificial water bodies across the United States landscape. The Science of the Total Environment, 299(1-3): 21-36.

SOUTHALL, H., PŘIDAL, P. (2012): Old Maps Online: Enabling global access to historical mapping. e-Perimetron, 7(2): 73-81.

SVANBERG, I., CIOS, S. (2014): Petrus Magni and the history of fresh-water aquaculture in the later Middle Ages. Archives of natural history, 41(1): 124-130.

ŠÁDKOVÁ, E., JÁNSKÝ, B. (2020): Splash dams in the Krkonoše Mts: from the history to their possible use. Geografie, 125(3): 291-317.
ŠARAPATKA, B., PAVELKOVÁ, R. (2020): Small bodies of Water which have Disappeared from the Czech Landscape and the Possibility of Restoring them. In: Zelenakova, M., Fialová, J., Negm, A. M. [eds.]: Assessment and Protection of Water Resources in the Czech Republic (pp. 127-143). Cham, Springer.

ŠIMŮNEK, R., ANTOŠ, F., HAVRLANT, J. (2014): Třeboň region in the First Military Survey. Historická geografie (Historical geography), 40(2): 153-204.

TEPLÝ, F. (1925): Dějiny rybníků na Hradecku. Vodňany, Rybářr.

THE MINISTRY OF AGRICULTURE OF THE CZECH REPUBLIC (2019): Ministerstvo pomůže s budováním dalších rybníků [online]. [cit. 30.07.2019]. Available at: http://eagri.cz/public/web/mze/tiskovy-servis/tiskovezpravy/x2019_ministerstvo-zemedelstvi-pomuze-s.html

THE MINISTRY OF THE AGRICULTURE OF THE CZECH REPUBLIC (2019): Ministerstvo zemědělství pomůže s budováním dalších rybníků, vodovodů a také opatření proti povodním. Získalo na ně půl miliardy korun navíc [online]. Available at: http://eagri.cz/ public/web/mze/tiskovy-servis/tiskove-zpravy/x2019_ ministerstvo-zemedelstvi-pomuze-s.html

THE MINISTRY OF THE ENVIRONMENT OF THE CZECH REPUBLIC (2020): Odborníci i politici stvrdili nová opatření pro boj se suchem, klíčové je zadržovat vodu - v nádržích, půdě i v urbanizovaném prostředí [online]. Available at: https://www.mzp.cz/ cz/news_20200512-odbornici-i-politici-stvrdili-novaopatreni-pro-boj-se-suchem-klicove-je-zadrzovat-vodu

TIMÁR, G. (2009): System of the 1:28,800 scale sheets of the second military survey in Tyrol and Salzburg. Acta Geodaetica et Geophysica Hungarica, 44: 95-104.

TORTORA, A., STATUTO, D., PICUNO, P. (2015): Rural landscape planning through spatial modelling and image processing of historical maps. Land Use Policy, 42: 71-82.

TRNKA, M., OLESEN, J. E., KERSEBAUM, K. C., SKJELVAG, A. O., EITZINGER, J., SEGUIN, B., et al. (2011): Agroclimatic conditions in Europe under climate change. Global Change Biology, 17: 2298-2318.

TRNKA, M., SEMERÁDOVÁ, D., NOVOTNÝ, I., DUMBROVSKÝ, M., DRBAL, K., PAVLÍK, F., VOPRAVIL, J., ŠTĚPÁNKOVÁ, P., VIZINA, A., BALEK, J., HLAVINKA, P., BARTOŠOVÁ, L., ŽALUD, Z. (2016): Assessing the combined hazards of drought, soil erosion and local flooding on agricultural land: a Czech case study: Climate Research, 70: 231-249.

TRANTINOVÁ, M. (2015): Udržitelné hospodaření s půdními a vodními zdroji. In: Rozkošný, M., Pavelková, R., David, V., Trantinová, M. [eds.]: Zaniklé rybníky v České republice: př́ipadové studie potenciálního využití území (pp. 25-42). Praha, Výzkumný ústav vodohospodářský T. G. M.

TRPÁKOVÁ, I. (2009). The use of historical sources and their ecological interpretation in the course of almost two centuries-a literature review. Journal of Landscape Studies, 2: 97-119.

UPEX, S. G. (2004): The Uses and Functions of Ponds within Early Landscapes in the East Midlands. The Agricultural History Review, 52(2): 125-140. 
YEH, C. T., HUANG, S. L. (2009): Investigating spatiotemporal patterns of landscape diversity in response to urbanization. Landscape and Urban Planning, 93: 151-162.

VÁVROVÁ, V., ŠANTRƯČKOVÁ, M. (2009): The landscape around Nové Dvory and Žehušice in the descriptions for the $1^{\text {st }}$ Military Mapping. Historická geografie, 35(1): 213-228.

VÝLETA, R., VALENT, P., DANÁČOVÁ, Z. (2020): Monitoring changes in the morphology and storage of a small water reservoir. A case study from Vrbovce, Slovakia. Slovak Journal of Civil Engineering, 28(2): 20-35.

WALTER, R. C., MERRITTS, D. J. (2008): Natural streams and the legacy of water-powered mills. Science, 319(5861): 299-304.
WILLIAMS, P., BIGGS, J., FOX, G., NICOLET, P., WHITFIELD, M. (2006): History, origins and importance of temporary ponds. Freshwater Forum, 17: 7-15.

WOOD, P. J., GREENWOOD, M. T., AGNEW, M. D. (2003): Pond biodiversity and habitat loss in the UK. Area, 35(2): 206-216.

ZIMOVÁ, R., PEŠŤÁK, J., VEVERKA, B. (2006a): Historical Military Mapping of Czech Lands-Positional Accuracy of Old Maps. GIM International, 20(10): 21-23.

ZIMOVÁ, R., PEŠŤÁK., J., VEVERKA, B. (2006b): Historical military mapping of the Czech lands-Cartographic Analysis. In: International Conference on Cartography and GIS, Borovets, Bulgaria (pp. 1-7).

\section{Please cite this article as:}

FRAJER, J., KREMLOVÁ, J., FIEDOR, D., PAVELKOVÁ, R., TRNKA, M. (2021): The importance of historical maps for man-made pond research: From the past extent of ponds to issues of the present landscape. A case study from the Czech Republic. Moravian Geographical Reports, 29(3): 184-201. doi: https://doi.org/10.2478/mgr-2021-0014 